\title{
The rise and fall of continental arcs: interplays between magmatism, uplift, weathering, and climate
}

\author{
Cin-Ty A. Lee ${ }^{1 *}$, Sally Thurner ${ }^{1}$, Scott Paterson $^{2}$, Wenrong $\mathrm{Cao}^{2}$ \\ ${ }^{1}$ Dept. Earth Science, Rice University, MS-126, 6100 Main St., Houston, TX 77005 \\ ${ }^{2}$ Dept. Earth Sciences, University of Southern California, 3651 Trousdale Pkwy, Los Angeles, \\ CA 90089-0740.
}

*corresponding author: ctlee@ rice.edu

Continental arcs, such as the modern Andes or the Cretaceous Sierra Nevada batholith, are some of the highest topographic features on Earth. Continental arc volcanoes may produce more $\mathrm{CO}_{2}$ than most other types of volcanoes due to the interaction of magmas with sedimentary carbonates stored in the continental upper plate. As such, global flare-ups in continental arc magmatism may amplify atmospheric $\mathrm{CO}_{2}$ concentrations, leading to climatic warming. However, the high elevations of continental arcs may also enhance orographic precipitation and change global atmospheric circulation patterns, possibly increasing the efficiency of chemical weathering and drawdown of atmospheric $\mathrm{CO}_{2}$, which may subdue the climatic warming response to volcanic activity. To better evaluate the climatic response, we develop models that integrate magmatic crustal thickening, topographic uplift, isostasy and erosion. The topographic response is used to predict how soil formation rates, soil residence times, and chemical weathering rates vary during and after a magmatic episode. Although magmatism leads to crustal thickening, which requires topographic uplift, highest elevations peak $\sim 10 \mathrm{My}$ after magmatism ends. Relatively high elevations, which enhance erosion and chemical weathering of the continental arc, persist for tens of million years after magmatism ends, depending on erosion kinetics. It has recently been suggested that the Cretaceous-Paleogene greenhouse (high atmospheric $\mathrm{CO}_{2}$ and warm climate) coincided with a global chain of continental arcs, whereas mid- to late Cenozoic icehouse conditions (low atmospheric $\mathrm{CO}_{2}$ and cold climate) coincided with a lull in continental arc activity after 50 Ma. Application of our models to the Sierra Nevada (California, USA) continental arc, which represents a segment of this global Cretaceous-Paleogene continental arc, reproduces the observed topographic and erosional response. Our models require that the newly formed continental arc crust 
remained high and continued to erode and weather well after ( $>50 \mathrm{My})$ the end of magmatism. Thus, in the aftermath of a global continental arc flare-up, both the total volcanic inputs of $\mathrm{CO}_{2}$ decline and the average weatherability of continents increases, the latter due to the increased proportion of widespread remnant topography available for weathering and erosion. This combination leads to a decrease in the long-term baseline of carbon in the ocean/atmosphere system, leading to cooling. Mid-Cenozoic cooling is often attributed solely to increased weathering rates associated with India-Eurasian collision and the Himalayan orogeny. However, the total area of now-extinct Cretaceous-Paleogene continental arcs is 1.3-2 times larger than that of the Himalayan range front and the Tibetan plateau combined, suggesting that weathering of these remnant volcanic arcs may also play a role in drawing down $\mathrm{CO}_{2}$ through silicate weathering and subsequent carbonate burial. In summary, if global continental arc flare-ups lead to greenhouse conditions, long-lived icehouse conditions should follow in the aftermath due to decreased $\mathrm{CO}_{2}$ inputs and an increase in regional weathering efficiency of remnant arc topography.

6

\section{Introduction}

Climate, that is, Earth's surface temperature, is modulated by solar insolation, albedo and greenhouse gas concentrations, such as $\mathrm{CO}_{2}$, in the atmosphere. Of interest here are long-term ( $>10 \mathrm{My}$ ) variations in Earth's climatic baseline. For example, Earth appears to vacillate between long (>50 My) warm intervals, where there are no significant continental ice sheets like the Cretaceous-Paleogene, to long cold intervals, where ice sheets are important, such as the mid-Cenozoic to present (Zachos et al., 2008). Compared to the Archean, when the sun was dimmer and there may have been fewer continents, long-term variations in solar insolation and albedo (mostly due to exposed continental surface area) during the Phanerozoic were not large enough to play an important role in long-term variation in climate (Caldeira and Kasting, 1992). This leaves variations in atmospheric $\mathrm{CO}_{2}$ as the primary influence on the long-term climatic baseline.

On >1 My timescales, the fluxes of carbon within the exogenic system, that is between the ocean, atmosphere and biosphere, are closely balanced, which means that long-term 
variations in atmospheric $\mathrm{CO}_{2}$ are controlled by inputs from the endogenic to the exogenic system via volcanism, metamorphism, and oxidative weathering of fossil organic carbon and by outputs from the exogenic system via silicate weathering and biological productivity in the form of carbonate and possibly organic carbon burial (Berner, 1991; Berner et al., 1983; Kerrick, 2001; Kerrick and Caldeira, 1994; Ridgwell and Zeebe, 2005; Walker et al., 1981). Silicate weathering rates scale with atmospheric $\mathrm{CO}_{2}$, hence carbonate precipitation represents a negative feedback (Walker et al., 1981). To illustrate, the rate of change of carbon in the ocean/atmosphere system on long timescales is given by

$$
\frac{d M_{o a}}{d t}=J_{i n}-k M_{o a}
$$

where $M_{o a}$ is the mass of carbon in the ocean+atmosphere system, $J_{\text {in }}$ represents volcanic and metamorphic degassing, and the second term represents carbonate deposition in response to silicate weathering with $k$ being a kinetic rate constant describing the global efficiency of weathering (e.g., weatherability). In reality, weathering rates (e.g., $k M_{o a}$ ) are a complex function of a wide variety of factors, so the linear kinetics assumed here are meant only to illustrate a concept. Thus, in Eq. 1, the inverse of $k($ e.g., $1 / k)$ is the response time of the ocean+atmosphere system to peturbations. Because the response time for silicate weathering and subsequent carbonate burial are less than $100 \mathrm{ky}$, inputs and outputs should be in balance and the global C system should be near steady state on timescales >1 My (Berner et al., 1983; Zeebe and Caldeira, 2008). Global $\mathrm{CO}_{2}$ drawdown via silicate weathering can only be as large as global $\mathrm{CO}_{2}$ inputs $J_{\text {in }}$.

Climate, however, clearly varies on timescales greater than $1 \mathrm{My}$, as evidenced by longlived greenhouse and icehouse oscillations throughout Earth's history. What drives these long term secular changes is one of the most perplexing problems in the Earth sciences. Since the left side of Eq. 1 is zero on long timesclaes, the long-term steady state carbon content in the ocean+atmosphere is given by

$$
M_{o a} \sim \frac{J_{i n}}{k}
$$

Thus, while global $\mathrm{CO}_{2}$ drawdown and $\mathrm{CO}_{2}$ inputs are balanced, long term changes in the actual carbon content of the atmosphere+ocean system are possible if there are changes in the external inputs driving the system $\left(J_{i n}\right)$ or in the overall weathering kinetics $(k)$ modulating the system or 
both. For example, secular variations in the dynamics of the Earth's deep interior might set $\mathrm{CO}_{2}$ inputs (Kerrick, 2001; Kidder and Worsley, 2010; Larson, 1991). Increased mid-oceanic ridge spreading and eruption of flood basalts have been suggested to have driven the long-lived (150$50 \mathrm{Ma}$ ) Cretaceous-Paleogene greenhouse (Berner, 1991; Hong and Lee, 2012; Kidder and Worsley, 2010; Larson, 1991). Mid-Cenozoic cooling has been suggested to be linked to IndiaEurasia collision and the rise of the Tibetan plateau, which led to enhanced kinetics of physical/chemical weathering (Edmond, 1992; France-Lanord and Derry, 1997; Raymo and Ruddiman, 1992; Zachos and Kump, 2005). Thus far, most studies treat changes in inputs and weatherability independently.

What happens when magmatism and mountain building are linked? Such may be the case for volcanic arcs. Volcanic arcs are a large source of $\mathrm{CO}_{2}$, which derives from background mantle $\mathrm{CO}_{2}$, decarbonation of subducted carbonates, and magmatically induced thermal metamorphism of carbonates in the upper plate (Burton et al., 2013; Dasgupta and Hirschmann, 2010; Hilton et al., 2002; Lee and Lackey, 2015; Lee et al., 2013; Marty and Tolstikhin, 1998). Averaged over 10-50 My, intra-oceanic arcs may not be as important as continental arcs in terms of net $\mathrm{CO}_{2}$ inputs into the exogenic system (arc flux minus subduction flux). This is because much of the carbonate subducted may just come back out through the volcanoes, or as recently suggested, some of the carbonate subducted may bypass the volcanic front, given modern thermal states of subducting slabs (Dasgupta, 2013; Kerrick and Connolly, 2001). It is in continental arcs, where the effect of upper plate carbonates may be most pronounced because continental margins serve as long-lived storage sites for sedimentary carbonate accumulated over a continent's history (Lee and Lackey, 2015; Lee et al., 2013). Magmatic interaction with upper plate carbonates can serve to enhance the magmatic flux of $\mathrm{CO}_{2}$ (Chadwick et al., 2007; Deegan et al., 2010; Toutain et al., 2009) such that changes in the global ratio of continental to island arcs might be expected to lead to variations in global $\mathrm{CO}_{2}$ inputs to the exogenic system. Global continental arc flare-ups, perhaps associated with super-continent dispersal, have been suggested as leading to greenhouse conditions in the Cretaceous-Paleogene (Lee et al., 2013). Continental arcs, however, are some of the highest elevations on Earth as exemplified by the modern Andean mountain belt in South America. They define long linear mountain belts on the margins of continents. Their high elevations might be expected to enhance erosion rates, which in turn may 
121 increase chemical weathering rates, culminating in more carbonate deposition and organic

122 carbon burial.

123 Continental arcs are thus a source and a sink for $\mathrm{CO}_{2}$. But to evaluate the role of

124 continental arcs on long-term climate variability, we must ask whether volcanism and weathering

125 are synchronized, and if not, to what extent are they out of phase? The answer to these questions

126 lies in understanding how magmatism, uplift and erosion are related. This paper is about the rise

127 and fall of continental arcs and the effect on climate.

128

129

130

131

132

133

134

135

136

137

138

139

140

141

142

143

144

145

146

147

148

149

150

151

\section{Controls on elevation and crustal thickness}

\subsection{Isostasy}

On long wavelengths $(>10 \mathrm{~km})$ and timescales (>10 ky), high elevations are controlled by isostasy, supported by either thickened, low density continental crust or anomalously hot, and hence low density, asthenospheric mantle. To first order, however, most high $(>2 \mathrm{~km})$ mountain belts are isostatically supported by largely thickened crust, as can be seen by the fact that high elevations $h$ generally correlate with crustal thickness $H$ (Fig. 1a). The slope of this correlation is controlled primarily by the effective integrated density contrast between the crust $\left(\rho_{c}\right)$ and mantle $\left(\rho_{m}\right)$,

which assumes differences in the density of crust beneath mountain belts and lowlands are small compared to the density contrast between the mantle and the crust (Fig. 2). Importantly, regions of high elevations (mountain belts) fall roughly along the same slope even though they are formed in very different tectonic settings; for example, the Andes represent a chain of continental arc volcanoes and the Tibetan plateau is formed by a largely amagmatic continentcontinent collision (Fig. 1a). We can thus assume that the average density of thick continental crust is similar, which implies that the primary control on high elevations is crustal thickness. There are, of course, some notable deviations. Antarctica and Greenland fall on a much steeper slope (not shown) because they are overlain by ice, which has a density of $1 \mathrm{~g} / \mathrm{cm}^{3}$, much lower than crustal and mantle rocks $\left(2.7-3.3 \mathrm{~g} / \mathrm{cm}^{3}\right)$. Some cratonal areas define slopes too shallow to be explained by any reasonable variation in crustal densities, and may be compensated by thermal density anomalies within the lithospheric mantle. In some cases, such as in northeastern Canada, the topography is not isostatically compensated due to delayed viscous response from 
rapid ice sheet unloading. Some high elevations are supported by anomalously hot asthenospheric mantle. Because we are concerned with timescales longer than the viscous response time of the mantle (10-100 ky), isostasy is always assumed. We also ignore the effects of density variations in the mantle because these effects represent deviations from the overall relationship between elevation and crustal thickness and are thus of secondary importance for this study.

\subsection{Interplay between magmatic thickening and erosion}

Crustal thickness represents the balance between addition and subtraction of mass to the crustal column (Fig. 2a). Crustal thickening is caused by magmatic inflation/underplating or tectonic shortening while thinning is caused by erosion/exhumation, delamination, or tectonic extension. The effects of tectonic thickening on erosion and climate have been extensively studied (Molnar and England, 1990; Willet and Brandon, 2002), but the effects of magmatic thickening have received almost no discussion despite many orogenic belts being associated with continental arc magmatic flareups, e.g., the Andes. In this paper, we are interested in the magmatic and geomorphic evolution of continental arcs and their potential effects on climate because recent studies have suggested that the length of continental arcs in the Cretaceous and early Cenozoic was substantially longer than that in the late Cenozoic (Lee et al., 2013) (Figs. 2a-c). For these reasons, we examine here the endmember in which thickness is modulated by magmatic additions and erosion; the equations are easily modified in the next section to account for tectonic thickening/thinning and delamination.

The rate at which crustal thickness $H$ changes is given by

$$
d H / d t=M-E
$$

where $M$ is magmatic volume flux $\left(\mathrm{km}^{3} / \mathrm{km}^{2} / \mathrm{My}\right)$ and $E$ is the erosion rate (km/My) (Fig. 1). We assume that erosion rate is proportional to average steepness $(h / w)$, that is, $E=\beta(h / w)$, where $h$ is the peak elevation of the magmatic mountain belt (relative to some regional base level), $w$ is the width of the magmatic belt, and $\beta$ is an erosional constant describing the efficiency of transport ( $\mathrm{km} / \mathrm{y})$ (Simoes et al., 2010). Because we are only interested in the average steepness of the mountain, not the mountain's overall morphology, we keep the width of the mountain constant, from which it follows that erosion rate is linearly related to elevation instead of slope (see Culling (1960) and Jadamec et al. (2007) for discussions modeling erosion 
via diffusion law). This is an obvious simplification, but allows us to develop an analytical solution when a forcing, such as magmatism, is applied. The erosional constant $\beta$ is related to the response time $\tau_{E}$ for erosion

$$
\tau_{E}=w / \beta
$$

$\tau_{E}$ is related to the product of precipitation rate $p(\mathrm{~mm} / \mathrm{y})$ and substrate erodibility $\left(\mathrm{m}^{-1}\right)$, that is (Simoes et al., 2010),

$$
\tau_{E}=\left(k_{e} p\right)^{-1}
$$

According to Simoes et al. (2010), $\tau_{E}$ ranges from 0.5-300 My across the globe. The low end (0.5 My) describes regions like Taiwan in which precipitation rates are high and bedrock is made up of easily erodible rocks like shales. The high end ( 25-300 My) describes arid regions like the Namibian craton where precipitation rates are orders of magnitude lower. Simoes et al. (Simoes et al., 2010) obtained a world-averaged $k_{e}$ of $1.84 \times 10^{-7} \mathrm{~m}^{-1}$. We cannot meaningfully ascribe an average precipitation rate for all continental arcs because precipitation rates will depend on the position and orientation of mountain belts relative to large scale atmospheric circulation patterns. For example, mountain belts in the intertropical convergence zone experience mean annual precipitation of $6-10 \mathrm{~mm} / \mathrm{d}$, whereas those at $30^{\circ} \mathrm{N}$ and $30^{\circ} \mathrm{S}$ may experience relatively dry climates (1-2 mm/d). We might also expect significant asymmetry in mean annual precipitation across a mountain belt due to rain-shadow effects. For example, in the central Andes, the mean annual precipitation in the eastern slope ranges from $2-8 \mathrm{~mm} / \mathrm{d}$ but on the western slope is less than $1 \mathrm{~mm} / \mathrm{d}$. We thus adopt a range of mean annual precipitation between 1-8 mm/d. Combining with the global average $k_{e}$ yields erosion timescales $\tau_{E}$ ranging from $\sim 14$ My for very arid conditions (mean annual precipitation $=1 \mathrm{~mm} / \mathrm{d}$ ) to $1.75 \mathrm{My}$ for relatively wet environments. Taking the global average mean annual precipitation of $2.67 \mathrm{~mm} / \mathrm{d}$ would yield a $\tau_{E}$ of $\sim 6 \mathrm{My}$.

Isostasy relates excess elevation $h$ to excess crustal thickness $H$ via $h=\left(1-\rho_{c} / \rho_{m}\right) H$ (see Sleep (1971) and Jadamec et al. (2007)). Combining all of the above equations yields an equation that describes how crustal thickness evolves

$$
\frac{d H}{d t}=M-\frac{1}{\tau_{E}}\left(1-\frac{\rho_{c}}{\rho_{m}}\right) H
$$




$$
H=M \tau_{L}\left(1-e^{-t / \tau_{L}}\right)+H_{o} e^{-t / \tau_{L}}
$$

where $H_{o}$ is initial crustal thickness before initiation of magmatism and $\tau_{L}$ is defined as

$$
\tau_{L} \equiv \tau_{E} /\left(1-\rho_{c} / \rho_{m}\right)
$$

which is the landform relaxation time, not to be confused with the erosion response time $\tau_{E}$. Equation 8 is similar in spirit to Equation 8 of Sleep (1971). The second term in Eq. 8 describes the rate at which crustal thickness thins by erosion if the magmatic production rate is zero. The first term describes the balance between erosion and magmatic production. When $t$ approaches infinity, crustal thickness reaches a steady state, e.g., $d H / d t=0$ in Eq. 7, wherein the erosion rate equals the magmatic production rate (Figs. 3a-c). Steady state thickness is given by

$$
H_{\infty}=M \tau_{L}=M \tau_{E} /\left(1-\rho_{c} / \rho_{m}\right)
$$

and steady state elevation by

$$
h_{\infty}=M \tau_{E} .
$$

At steady state, crustal thickness and elevation depend on magmatic production rate and the erosion rate constant: high magmatic production rate yields thick crust and high elevations while a high erosion rate constant yields thinner crust and lower elevations. Note that steady state crustal thickness is influenced by isostasy because the term $\left(1-\rho_{c} / \rho_{m}\right)$ in Eq. 10 is non-zero. Steady state elevation, however, is independent of isostasy. This is obvious from the lack of the isostatic term in Eq. 11, but also follows intuitively from the fact that erosion rate is directly controlled by elevation and only indirectly controlled by crustal thickness.

The time it takes for the landform to approach steady-state (so-called "equilibrium" landscape) is given by Eq. 9, which states that elevation responds to magmatic thickening on timescales dictated by the kinetics of erosion and modulated by the effects of isostasy, but not on the magmatic production rate (if it is constant). If the erosion timescale $\tau_{E}$ is short, then landforms (e.g., average surface elevation) respond and attain steady state rapidly. The contribution of isostasy (in the form of density contrast between crust and mantle) to the landform response time $\tau_{L}$ is substantial (Sleep, 1971). For a crustal density of $2.87 \mathrm{~g} / \mathrm{cm}^{3}$ and a mantle density of 3.33 , the landform response time $\tau_{L}$ is $\sim 6.6$ times greater than the erosional time $\tau_{\mathrm{E}}$ due to isostasy. To illustrate, consider a mountain $1 \mathrm{~km}$ above baseline. If the mountain is not isostatically compensated by a root (i.e., $\rho_{c}=0$ or if the mountain is supported elastically), then eroding only $1 \mathrm{~km}$ of crust is sufficient to bring elevations back to base-level. However, if 
the mountain is isostatically compensated by a buoyant root, $6 \mathrm{~km}$ of rock must be eroded to return to base-level because erosion leads to rock uplift (England and Molnar, 1990). Failure to account for isostasy leads to under-estimation of the timescales of geomorphic equilibration.

These concepts are illustrated in Figure 3a-c for an instantaneous magmatic influx, which is held constant. The scenario presented here is clearly unrealistic and is only meant to illustrate the behaviors described above. We have assumed $M$ to be constant at $3 \mathrm{~km} / \mathrm{My}$ and considered three erosional response times: $1.5,6$, and $15 \mathrm{My}$. The landform response times required to reach steady state elevations are clearly evident from the figures. It can also be seen that if magmatism is sustained at such high levels for $>20 \mathrm{My}$, unrealistically high elevations and crustal thicknesses are attained for erosional response times of 6 and $15 \mathrm{My}$. The fact that we do not see such high elevations and crustal thicknesses in nature must mean that erosional timescales are shorter, magmatic fluxes are smaller, or the duration of sustained magmatic activity in one given location is shorter than the values assumed in this thought experiment. An additional problem is that there is no limit to how deep the crust can grow. The generation of dense mafic cumulates in the lower crust, followed by their foundering, provides a way of limiting crustal thickness by basal processes. Below, we discuss coupled effects of cumulate foundering and erosion.

\subsection{The effect of dense cumulate formation and lower crustal foundering}

It is well-known that the lower crust in thick $(>45 \mathrm{~km})$ arcs consists of mafic cumulates and restites in the form of garnet pyroxenites (DeBari and Sleep, 1991; Ducea and Saleeby, 1996; Greene et al., 2006; Jagoutz and Schmidt, 2012; Lee, 2014; Lee et al., 2006; Lee et al., 2007). Garnet pyroxenites are denser than peridotitic mantle, so they should founder into the mantle once critical thickness is attained. The value of this critical thickness is likely to be highly variable as it depends on density and viscosity of the pyroxenite, the latter depending on temperature. In some places, like the Sierra Nevada batholith, it is clear that a garnet pyroxenitebearing layer extending from $\sim 45 \mathrm{~km}$ depth down to at least $70 \mathrm{~km}$ (lithosphere thickness may have extended to depths $>90 \mathrm{~km}$ ) developed in the late Cretaceous and persisted until the late Miocene before foundering (Ducea and Saleeby, 1996; Lee et al., 2006). As the pyroxenite layer 
271 grows in thickness, surface elevations subside due to the growing mass excess in the crustal

272 column (Fig. 2b). Elevation $h$ is given by

273

$$
h=\frac{\rho_{p x}-\rho_{c}}{\rho_{m}} h_{p x}+\left(\frac{\rho_{c}}{\rho_{m}}-1\right) H_{b}+\left(1-\frac{\rho_{p x}}{\rho_{m}}\right) H_{t o t}
$$

274 where $\rho_{\mathrm{px}}, \rho_{\mathrm{c}}$, and $\rho_{\mathrm{m}}$ are the densities of the pyroxenite, normal crust, and mantle, $h_{p x}$ is the

275 depth at which pyroxenite begins to form, $H_{b}$ is the thickness of the background crust (e.g., at sea

276 level), and $H_{t o t}$ is the total thickness of the crust, including the pyroxenite layer. The thickness of

277 the pyroxenite layer $H_{p x}$ is given by $H_{t o t}-h_{p x}$. Thus, the change in elevation per change in

278 pyroxenite layer thickness is given by (Lee, 2014)

279

$$
\frac{d h}{d H_{p x}}=\left(1-\frac{\rho_{p x}}{\rho_{m}}\right)
$$

280

281

282

283

284

285

286

287

288

289

290

291

292

293

294

295

296

297

298

299

Equation 13 is applicable to both thickening and thinning of the pyroxenite layer. Thus, if the pyroxenite layer thins, perhaps by foundering, elevations rise again. Incorporating equations 12 and 13 into the mass transport equations in the previous section is best done numerically by considering the amount of pyroxenite to represent the fraction of the crust that lies deeper than the depth at which pyroxenite begins to form. In all of these calculations, we are interested in timescales longer than 10-100 ky, such that all long wavelength mountain ranges can be assumed to be in isostatic equilibrium.

The effects of pyroxenite formation for constant magmatic forcing can be seen in Figure $3 \mathrm{~d}$-f. Here, we have assumed $h_{p x}=65 \mathrm{~km}, H_{p x}=35 \mathrm{~km}$ and $\rho_{\mathrm{px}}=3.5 \mathrm{~g} / \mathrm{cm}^{3}$. This means that garnet pyroxenite forms at depths greater than $65 \mathrm{~km}$ and after if reaches $35 \mathrm{~km}$ in thickness, it undergoes rapid wholesale foundering back into the mantle, resetting the crustal thickness to 65 $\mathrm{km}$. Our models show that crustal thickness and elevation rise up and down with a sawtooth pattern. When crustal thickness exceeds $65 \mathrm{~km}$, the formation of a growing pyroxenite layer causes a gradual drop in elevation. When the pyroxenite layer thickness exceeds $35 \mathrm{~km}$, the pyroxenite is removed rapidly (instantaneously in our model), resulting in a rapid return to high elevations. But since we have assumed a constant sustained magmatic flux M, elevations start to decline again because the pyroxenite layer resumes growing. Note that if erosion response times are short (efficiency of erosion is high), then erosion is efficient enough to limit crustal thickness from growing beyond $65 \mathrm{~km}$, preventing dense pyroxenite formation. 
There are other processes that we did not consider here. One is the effect of arc front migration. The second is the effect of tectonics on thickening or thinning the upper plate in magmatic arcs. Tectonic effects on climate have been explored in depth, but how magmatism influences tectonic shortening rates, for example, or how tectonics influences magmatism, have not been explored in great detail. One could envision magmatism weakening the lower crust by heating it up, thereby decreasing the resistance to tectonic forces. In addition, thickening of the upper plate decreases the "headspace" for decompression melting, and thus, magmatic thickening may itself be a self-limiting process (Karlstrom et al., 2014). Finally, we have not considered gravitational collapse in our models (Bird, 1991; Jadamec et al., 2007; Molnar and Lyon-Caen, 1988).

\section{Application to the Cretaceous Sierra Nevada magmatic flare-up in North America}

\subsection{Forward models with non-steady magmatic production rates}

We now consider the more realistic scenario in which magmatic production rate $\dot{M}$ is not constant, requiring Eq. 2 to be solved numerically. We motivate our model with the Cretaceous Sierra Nevada and Peninsular Ranges batholiths in California, USA (Fig. 4), which flared up most recently between 120 and $~ 85$ Mya (My ago) based on a compilation of U-Pb zircon ages in sediments and plutons (Ducea and Barton, 2007; Ducea et al., 2015; Paterson and Memeti, 2014; Paterson et al., 2014; Paterson et al., 2011) (Fig. 5a). During this 40 My interval, magmatic flux rises, peaks at $\sim 95 \mathrm{Ma}$, and then declines. What leads to long-lived magmatic flare-ups in continental arcs is unclear, but possibilities include changes in plate motion, lithospheric thinning by delamination/convective removal, and underthrusting of continental lithosphere in the back-arc region (Ducea and Barton, 2007 ). The eventual decline and termination of magmatism could be caused by thickening of the arc crust (e.g., by magmatism), which limits the extent of decompression melting in the asthenosphere (Chin et al., 2015; Karlstrom et al., 2014). For the purposes of this paper, we take the observed flareup as given.

To simulate the growth of the Sierran arc, constraints on the magmatic flux, that is, the volume flow rate per unit area (e.g., $\mathrm{km} / \mathrm{Ma}$ or $\mathrm{km}^{3} / \mathrm{km}^{2} / \mathrm{Ma}$ ), are needed. Flux is a difficult quantity to obtain because only the area of exposed plutons and their ages can be obtained. The 
vertical dimension of plutons cannot be directly obtained because the rocks of interest are either already eroded or in the subsurface. Nevertheless, it may still be possible to approximate average, arc-wide fluxes. Figure $5 \mathrm{~b}$ shows the total volume of magmas added to the crust per million year estimated by determining the total surface area of plutons in the Sierra Nevada batholith per age, multiplying by a nominal value of $30 \mathrm{~km}$, which corresponds to the thickness of the crust as defined by the Moho, and adjusting this volume based on the total percent of plutonic versus host rocks established from maps for different depths of the crust (Paterson and Ducea, 2015). This total magmatic addition can then be averaged per area of arc. Estimated in this way, the volume flow rate peaks at $\sim 1.5 \times 10^{5} \mathrm{~km}^{3} / \mathrm{My}$ at $\sim 95 \mathrm{Ma}$. Dividing the volume flow rate by total area of the batholith $(\sim 800 \mathrm{~km} \times 100 \mathrm{~km})$ yields a peak magmatic flux of $\sim 1.8$ $\mathrm{km} / \mathrm{My}$. If mafic cumulates are considered as part of the magmatic flux, the estimated flux is doubled to $\sim 3.6 \mathrm{~km} / \mathrm{My}$, assuming a $\sim 1: 1$ ratio of felsic crust to mafic cumulates. It is likely that these estimates of magmatic addition are minimum bounds because erosion was not considered in the calculations. However, knowing the exact number is not crucial because we are interested primarily in general trends of magmatically evolving mountain belts. We will consider peak magmatic fluxes between 1.8-3.6 km/My in our forward models.

To simulate the Sierran magmatic flareup, we assume that magmatic flux is zero at 120 $\mathrm{Ma}$, rises linearly to the peak magmatic flux at $100 \mathrm{Ma}$, and then declines linearly to zero by 80 Ma. We have chosen to keep the magmatic evolution with time linear and symmetric, mainly to keep the model simple and general. We assume a reference mantle density $\rho_{m}$ of $3.33 \mathrm{~g} / \mathrm{cm}^{3}$ (Lee, 2003). We assume an average continental crust density of $\rho_{c}$ of $2.87 \mathrm{~g} / \mathrm{cm}^{3}$, which we take as the best fit of equation 1 to the elevation $(h)$ versus crustal thickness $(H)$ data of mountain belts $(h>2 \mathrm{~km})$ in Figure 1. This regression also gives us an estimate of the baseline thickness of $h_{b}=30 \mathrm{~km}$ of continental crust at sea level (e.g., at the continental margin). We consider erosion response times $\tau_{E}$ of $1.8,6$, and $16 \mathrm{My}$ to explore the full range of behaviors. These erosion response times correspond to landform relaxation timescales of $\tau_{L}$ are $\sim 11, \sim 36$ and $\sim 84 \mathrm{My}$.

We first consider the case in which no garnet pyroxenite forms. Model results are shown in Figure 6 for magmatic fluxes with peak flux $M_{\max }=1.8 \mathrm{~km} / \mathrm{My}$ and $3.2 \mathrm{~km} / \mathrm{My}$. Because $M$ is not constant, the system is never at steady state. Peak erosion is of course delayed after peak magmatism, but depending on erosion kinetics $\left(1 / \tau_{E}\right)$ the delay can range from 5 to $20 \mathrm{My}$. For erosion response times of $1.5 \mathrm{My}$, erosion nearly keeps up with magmatism as expected: the 
erosional flux is concentrated in a narrow pulse, resulting in high erosional fluxes just after peak magmatism; maximum elevations and crustal thicknesses are limited. For longer erosional response times (e.g., 6-15 My), erosion rates are low, which slows down the decrease in crustal thickness and elevation, resulting in a long and protracted (>50 My) post-magmatic interval of erosion. For peak magmatic flux of $1.8 \mathrm{~km} / \mathrm{My}$, we obtain peak elevations between $1-4 \mathrm{~km}$ for the range of erosional response times considered here. For reasons discussed above, a peak magmatic flux of $3.2 \mathrm{~km} / \mathrm{My}$ is likely more realistic for the Sierra Nevada, but this results in peak elevations of 6-8 $\mathrm{km}$ for erosional response times of 6 and $15 \mathrm{My}$, which seem unrealistic.

Peak elevations, however, will be suppressed if the crust thickens enough to stabilize garnet pyroxenite in the lower crust. To explore this effect, we define the critical depth at which garnet pyroxenite forms to be $h_{p x}=65 \mathrm{~km}$, the critical thickness of the pyroxenite prior to foundering to be $H_{p x}=35 \mathrm{~km}$, the density of pyroxenite $\rho_{p x}$ to be $3.5 \mathrm{~g} / \mathrm{cm}^{3}$, which is $5 \%$ denser than our nominal mantle density of $3.33 \mathrm{~g} / \mathrm{cm}^{3}$. Clearly, temperature contrast between the crust and the mantle plays a strong role in density contrast, but garnet pyroxenite densities can also vary from 1-10\% relative to the mantle due to composition alone (Lee et al., 2006). The mafic pyroxenite layer may also be interleaved with peridotites. This density contrast of 5\% is thus chosen to encapsulate the integrated compositional and temperature effects on density in the mafic lower crust. Similarly, the depth at which garnet pyroxenite forms depends on bulk composition, and given the transitional nature of crustal composition with depth, our choice of $h_{p x}$ is only considered approximate. Again, our interest lies evaluating the effect of parameter variability in overall trends and behavior.

The effects of pyroxenite formation on crustal thickening and elevation change are shown in Figure 7. Only the case for $M_{\max }$ of $3.2 \mathrm{~km} / \mathrm{My}$ is shown because the crust never reaches thicknesses that exceed $h_{p x}$ of $65 \mathrm{~km}$ for the case in which peak $M_{\max }$ is $1.8 \mathrm{~km} / \mathrm{My}$ and thus remains unchanged from Figure 6a-d. It can be seen from Figure 7 that once crustal thickness exceeds $65 \mathrm{~km}$, elevation stops rising, and because elevations are subdued, erosion rates cannot continue to rise. In fact, continued thickening of a pyroxenite layer due to progressive magmatic addition causes elevations and erosion rates to decrease. However, once magmatism ends, erosion will thin the crust, and in so doing, the thickness of the pyroxenite layer $H_{p x}$ also decreases because the top of the layer is transported to depths shallower than the pyroxenite transition $h_{p x}$ and metamorphoses back into plagioclase-bearing rock. Thus, after magmatism 
ends, surface elevation rises slightly. But once the pyroxenite layer is completely converted to plagioclase-bearing lithologies, that is, crustal thickness decreases below $h_{p x}$ of $65 \mathrm{~km}$, elevations subside again because the only control on elevation is crustal thickness (not vertical density variations). In our models, it can be seen that for very short erosional response times (1.5 My), pyroxenite never forms because the crust never thickens sufficiently. Only for higher erosional response times (6 and $16 \mathrm{My}$ ) does the pyroxenite layer form; in both of these cases, elevations peak at $\sim 4 \mathrm{~km}$ followed by a long ( $>50 \mathrm{My}$ ) tail of sustained high elevations.

\subsection{Comparison to Sierran geomorphic evolution}

The most important conclusion of our analysis is that magmatic flare-ups are accompanied by erosion and that high elevations can persist long after magmatism ends. U$\mathrm{Th} / \mathrm{He}$ thermochronology and coupled studies of pluton barometry and U-Pb geochronology provide some constraints on the paleo-depths of plutons as a function of time (Ague and Brimhall, 1988; Cecil et al., 2006; House et al., 1998; House et al., 1997; Paterson et al., 2014; Wakabayashi and Sawyer, 2001) as can be seen in Figure 5. These paleo-depth-time constraints can be used to place bounds on erosion rates, which we show in Figure 8 in comparison to our modeled erosion rates. What is clear is that observed erosion rates are low before $100 \mathrm{Ma}$, highest between 100-50 Ma, and low again between 50-0 Ma. That is, erosion rates are low before magmatism and are highest during the latter half of the magmatic flare-up, with high erosion rates continuing for $30 \mathrm{My}$ after magmatism terminates. Our observations indicate a delayed erosional response. Erosional response times of $1.5 \mathrm{My}$ are too short to explain the observations and response times of $15 \mathrm{My}$ appear to be too long. This suggests that the appropriate erosional response time to adopt is intermediate, consistent with the global average response time of $6 \mathrm{My}$ used here. We note that our models for $\mathrm{M}=1.8$ and $3.2 \mathrm{~km} / \mathrm{My}$ for erosional response times of $6 \mathrm{My}$ (with or without pyroxenite formation) are all consistent with the observations to within error (Fig. 8a). Based on earlier discussions, however, a peak magmatic flux of $1.8 \mathrm{~km} / \mathrm{My}$ is most certainly a minimum bound and a value of $\sim 3 \mathrm{~km} / \mathrm{My}$ may be more reasonable.

Adopting $M_{\max }$ of $3.2 \mathrm{~km} / \mathrm{My}$ and an erosional constant of $6 \mathrm{My}$, we find that models that do not allow for garnet pyroxenite formation yield peak elevations of $6 \mathrm{~km}$, but when pyroxenite formation is included, peak elevations are $4 \mathrm{~km}$. We can compare our model outputs to paleo- 
423 altimetry constraints. Elevations prior to the Cretaceous magmatic flare-up were likely low or close to sea-level based on the fact that Cretaceous plutons intruded into 150-190 Ma old marine sediments throughout the Sierras, such as the Mariposa Formation (Cao et al., 2015; Paterson et al., 2014). Oxygen isotopic constraints suggest elevations reached $\sim 3 \mathrm{~km}$ by $\sim 85 \mathrm{Ma}$, indicating that magmatism was accompanied by surface uplift (Poage and Chamberlain, 2002). These high elevations may have persisted until the Miocene (Poage and Chamberlain, 2002). Today, the Sierran crest reaches $\sim 4 \mathrm{~km}$ high, but given the sparse data constraints, it is not clear if these high elevations represent residual Cretaceous elevations or if they reflect late Cenozoic uplift. Indeed, the western Sierra Nevada foothills are characterized by over-steepened Miocene paleochannels, which indicates that there has been significant westward tilting and crest uplift in the Pliocene uplift (Huber, 1981). There is insufficient data to evaluate whether Sierran elevations decreased in the mid-Cenozoic and rose again or whether elevations have remained high ever since magmatism terminated $\sim 80$ Ma ago. Our model results, however, would suggest that elevations may have subsided, but only moderately, such that elevations still remained at $2 \mathrm{~km} \sim 40 \mathrm{Ma}$ ago. Pliocene uplift could have been superimposed on this gradual but moderate decline in elevation.

\section{Continental arc volcanism and regional chemical weathering}

It is natural now to explore the effects of uplift and physical weathering on regional chemical weathering. We assume that chemical weathering occurs primarily when the rock is in residence in the soil mantle overlying the bedrock, where soil is distinguished from bedrock in having higher porosity owing to chemical weathering and bioturbation. Soil formation processes occur on timescales much faster and length scales much shorter than secular changes in orogenic activity, so the details of soil formation on overall erosion rates was ignored in Section 2. However, as we show below, chemical weathering fluxes are strongly influenced by soil residence time because it dictates what fraction of the physically eroded material is chemically weathered (dissolved).

The rate at which the soil mantle thickness $z$ changes is a competition between the rates of bedrock-to-soil production $P(\mathrm{~km} / \mathrm{My})$ and erosion $E(\mathrm{~km} / \mathrm{My})$ that is,

$$
d z / d t=P-E
$$


452 Here, we assume that $P$ and $E$ are representative averages of the mountain and that $E$, as

453 described in Eq. 4, depends on average topographic gradient. We assume that the soil formation 454 rate decays exponentially with depth in the soil mantle, that is,

$$
P=P_{o} e^{-z / D}
$$

where $P_{o}$ is the bedrock to soil production rate of fresh bedrock surface (e.g., when soil mantle thickness is zero) and $D$ is the characteristic lengthscale over which soil production decays with depth (Heimsath et al., 1997) (Fig. 9a). This equation requires that $P_{o}>E$ at all times. The decay lengthscale $D$ describes how the efficiency of bedrock to soil conversion decreases with depth; $D$ should be large when precipitation rate, bioturbation and/or bedrock permeability (fracture density) is high. Combining equations 14 and 15 leads to a differential equation, which can be integrated to yield soil mantle thickness versus time

$$
z=D \ln \left[\frac{P_{o}}{E}+\left(e^{z_{o} / D}-\frac{P_{o}}{E}\right) e^{-E t / D}\right]
$$

It can be seen that if $P_{o}=E$, an infinitesimally small soil mantle forms (e.g., $z=0$ ), that is, erosion and bedrock-to-soil conversion at the surface are equal. Eq. 16 also indicates that soil mantle thickness reaches steady state when $t$ is longer than the soil formation response time

$$
\tau_{S}=D / E
$$

The steady state soil mantle thickness is given by (Heimsath et al., 1997)

$$
z_{\infty}=D \ln \left(P_{o} / E\right)
$$

which is attained if $\tau_{S}$ is less than the landform relaxation time $\tau_{L}$. Figure $9 \mathrm{~b}$ shows soil mantle thickness $\mathrm{z}$ as a function of time for different net erosion rates $\mathrm{E}$. When erosion rates are high (due to high elevations and high magmatic production), soil mantle thickness is very thin. When erosion rates are low, thick soil mantles develop. Steady state soil mantle thickness is attained rapidly when erosion rates are high.

We now evaluate chemical weathering fluxes. We assume that most of the chemical weathering occurs in the soil profile. We ignore weathering in river bedload and in depositional basins because we assume that bedload is evacuated quickly in mountainous regions and sedimentation rates in orogenic-driven basins is too fast to permit significant post-depositional weathering. We consider chemical weathering associated with soil formation for the condition in 
which $\tau_{S}$ is less than $\tau_{L}$. At steady state soil mantle thickness, the residence time of any particle in the soil mantle is given by

$$
\tau_{\text {res }}=\frac{z_{\infty}}{E}=\frac{D}{E} \ln \left(\frac{P_{o}}{E}\right)=\tau_{S} \ln \left(\frac{P_{o}}{E}\right)
$$

For a given soil mantle thickness, the higher $E$ is, the shorter the residence time (Fig. 9c). The mass fraction of material in the soil mantle that remains after dissolution $f_{w}$ should decrease with increasing residence time of a particle in the soil mantle. The quantity $f_{w}$ represents the availability of weatherable material, that is, $f_{w}=1$ corresponds to relatively unaltered bedrock and $f_{w}=0$ corresponds to a highly depleted residue (e.g., a laterite would be an extreme case of weathering).

To describe how $f_{w}$ evolves with time, we adopt an inverse time relationship following Maher and Chamberlain (Maher and Chamberlain, 2014)

$$
f_{w}=\left(1+k_{w} \tau_{\text {res }}\right)^{-1}
$$

where $k_{w}$ is the inverse response time $\left(\mathrm{s}^{-1}\right)$ and is a function of the dissolution rate constant (which depends on $\mathrm{pCO}_{2}, \mathrm{pH}$, mineral composition, etc.) and the effective surface area of mineral grains in the soil mantle (Maher and Chamberlain, 2014). A high $k_{w}$ implies more efficient or rapid chemical weathering and faster approach to $f_{w}=0$. For a given $k_{w}$, when the residence time of particles in the soil mantle is short, weathering intensity is small so $f_{w}$ approaches 1 . When the residence time is high, weathering intensity is high so that $f_{w}$ approaches zero and saprolitic or lateritic soils are generated. The time-integrated fraction of material lost by dissolution is $1-f_{w}$. The time-integrated chemical weathering flux $W$ is then

$$
W=E\left(1-f_{w}\right)
$$

that is, the chemical weathering flux is controlled by the physical weathering flux $E$ and the intensity of weathering $\left(1-f_{w}\right)$. Maher and Chamberlain emphasize a link between riverine solute flux and water flow (runoff) and suggest that regional chemical weathering fluxes can thus be predicted by runoff. We do not model runoff here, and instead, relate weathering flux to erosion, but the outcome of our weathering calculations should be similar. Global compilations of river chemistry show that runoff and erosion correlate, so chemical and physical erosion also correlate (Gaillardet et al., 1999; Millot et al., 2002). High elevations should also increase runoff rates due to increased orographic precipitation (Maher and Chamberlain, 2014; Montgomery et al., 2001). 
The development of soil mantles and chemical weathering fluxes can be evaluated if values of $\mathrm{P}_{\mathrm{o}}, \mathrm{D}$ and $k_{w}$ are known. These quantities will undoubtedly vary as a complicated function of biology, precipitation rate, $\mathrm{pCO}_{2}$, bedrock composition, and soil and bedrock permeability (West, 2012). Calibrating this functional relationship requires empirical constraints from the field or laboratory, which are currently too sparse to span all relevant variable space. Maher and Chamberlain (2014) adopt of chemical weathering decay time $\left(1 / \mathrm{k}_{\mathrm{w}}\right)$ of $\sim 10 \mathrm{ky}$ appropriate for granitic systems, but given that $k_{w}$ depends on reactive surface area, which itself can vary by an order of magnitude in granitoids, this number should be considered approximate. Dixon et al. (2012) estimate values of $\mathrm{P}_{\mathrm{o}}(\sim 0.23 \mathrm{~km} / \mathrm{My})$ and $\mathrm{D}(\sim 30 \mathrm{~m})$ for the currently uplifting San Gabriel Mountains in southern California. If we adopt these numbers, we find that the chemical weathering flux goes to zero between the peak of magmatism and $25 \mathrm{My}$ after magmatism terminates, after which it rises (Fig. 10). This is because physical erosion rates $E$ exceed the maximum bedrock-to-soil production rate. The San Gabriels, however, represent an unusually arid endmember (Dixon et al., 2012) so $\mathrm{P}_{\mathrm{o}}$ and D might be expected to be significantly higher for larger mountain ranges, which tend to induce more orographic precipitation. Adopting a higher value for $P_{o}$ will give finite chemical weathering rates (Fig. 10), but even if we adopt an unusually high value of $1 \mathrm{~km} / \mathrm{My}$, chemical weathering rates are subdued when elevations are highest (or more accurately, when average slope is highest) and physical weathering rates are highest. For example, if we assume $P_{o}$ of $0.8 \mathrm{~km} / \mathrm{My}$, we obtain finite chemical weathering rates, but such rates are low during and immediately after the magmatic flare-up, only to increase $\sim 20$ My after magmatism ends. Adopting an even higher $P_{o}$ of 1 $\mathrm{km} / \mathrm{My}$ would increase syn-magmatic chemical weathering rates, but a long tail of chemical weathering will continue to persist for $>50 \mathrm{My}$ after magmatism ends. In summary, chemical weathering and physical erosion in general correlate, but at very high erosion rates, chemical weathering is kinetically limited by the short residence time of rock in the soil mantle on eroding landscapes (Dixon et al., 2012; Ferrier and Kirchner, 2008; Hilley et al., 2010; West et al., 2005). It is during the geomorphic relaxation of the residual topography, where erosion rates are high, but not too high, that chemical weathering fluxes are highest (Fig. 10). Our models thus predict a long (>50 My) tail of enhanced regional chemical weathering after magmatism wanes.

Finally, another prediction of our model is how the composition of the weatherable substrate evolves. As shown in Figures 10d and e, when elevations and erosion rates are high, 
the substrate would be geochemically more juvenile, that is, closer to original magmatic compositions. As elevations subside and erosion rates decline, the substrate would be represented by more deeply weathered lithologies, perhaps approaching lateritic compositions under the right climatic conditions. Saprolites are abundant throughout the Sierra Nevada, and based on the fact that they are capped by Eocene gravels and Miocene lava flows, these saprolites must have formed before the Eocene (Lindgren, 1911). A powerful test of the concepts introduced here would be to investigate how the alteration degree (such as the Chemical Index of Alteration) of siliciclastics shed off of the Sierra Nevada and into the Great Valley changes with time. Our models predict alteration degree to be low in the late Cretaceous and high in the Cenozoic.

\section{Implications for long-term climate change: icehouse-greenhouse pairs}

Although we have focused our discussions so far on the Sierra Nevada, California, the Sierras are only part of a global chain of continental arcs that were active during the Cretaceous and early Paleogene (Bateman and Eaton, 1967; Ducea et al., 2015; Lee et al., 2013). This chain of continental arcs extended along the southern, southeastern and eastern margins of Eurasia and along the entire western margins of North and South America, altogether totaling 33,000 km, which is $200 \%$ longer than the length of continental arcs in the mid-Cenozoic to present (Lee et al., 2013) (Fig. 4c). Much of the continental arc magmatism in western North America waned by the mid-Cenozoic. All of the southern and southeastern Eurasian continental arcs terminated $~ 50$ Ma due to the collision of India with Eurasia and large-scale rollback in the western Pacific, which culminated in the formation of the Tonga-Izu-Bonin-Kermadec island arc system $~ 52 \mathrm{Ma}$ (Ishizuka et al., 2014). Lee et al. (2013) have suggested that this global flare-up of continental arc volcanism may have led to greenhouse conditions of the Cretaceous and early Paleogene because many of the continental arc volcanoes intersected and interacted with ancient crustal carbonates stored on the continental upper plate (Fig. 4c); by contrast, the upper plate in intraoceanic settings has comparatively less carbonate. As a consequence, this flare-up in continental arc volcanism and associated decarbonation of crustal carbonates may have led to enhanced $\mathrm{CO}_{2}$ outputs from the Earth's interior (Dasgupta, 2013; Lee and Lackey, 2015; Lee et al., 2013). The second consequence of such an extensive flare-up of continental arcs in the CretaceousPaleogene is a >50 My aftermath of relict topography underlain by relatively juvenile crust susceptible to sub-aerial chemical weathering. Widespread occurrence of saprolite in the Sierra 
571 Nevada and Peninsular Ranges batholiths and in the batholiths of southern and eastern China,

572 attest to prolonged and continued weathering of the Cretaceous-Paleogene arcs (Lindgren, 1911).

573 Mid to late Cenozoic cooling has often been attributed to the rise of the Tibetan plateau,

574 leading to global increases in weatherability and efficiency of $\mathrm{CO} 2$ removal. Here, we suggest

575 that both long-term greenhouses and icehouses are ultimately controlled by external drivers of

$576 \mathrm{CO}_{2}$ inputs from the endogenic to the exogenic system, that is, on long timescales weathering

577 outputs of $\mathrm{CO}_{2}$ are only as high as that supported by volcanic+metamorphic inputs (Berner and

578 Caldeira, 1997). Thus, when inputs are high (continental arc stage), atmospheric $\mathrm{pCO}_{2}$ is high,

579 and when inputs subside (island arc stage), atmospheric $\mathrm{pCO}_{2}$ subsides (see Eq. 2). We suggest

580 that the rise and fall of global continental arc flare-ups may be the primary driver of greenhouse

581 and icehouse fluctuations. Cooling in the aftermath of a flare-up may be further enhanced

582 because of the increase in regional weatherability due to the large areas of remnant arc

583 topography. While the weathering rate per unit area of the Himalayan front is likely much

584 higher than that of remnant arc topography because of more active tectonics in the former, the

585

586

587

588

589

590

591

592

593

594

595

596

597

598

599

600

601 total weathering output associated with remnant arcs may nonetheless be significant. The area of the Tibetan plateau is 2.5 million $\mathrm{km}^{2}$, whereas the Cretaceous-Paleogene continental arcs generated 3.3-5 million $\mathrm{km}^{2}$ of elevated relict topography assuming an arc width of $100-150 \mathrm{~km}$ (Lee et al., 2013). Furthermore, most of the chemical weathering in Tibet occurs in narrow belts along the southern and eastern margins of the plateau where orographic effects are strongest $(\mathrm{Wu}$ et al., 2008). By contrast, continental arcs are long and narrow, hence a greater fraction of volcanic arc mountain belts might be expected to undergo chemical weathering than the Tibetan plateau (although the intensity of weathering would be less in the remnant arcs). Thus, if a global Cretaceous-Paleogene continental arc system indeed existed, their topographic remnants must have contributed a significant proportion of the global chemical weathering sink in the mid to late Cenozoic, with or without India-Eurasian collision. Whether these remnant arcs are more important than the Himalayan orogeny in terms of weathering flux cannot be answered in this study. Our study suggests that the exact role of Himalayan weathering in Cenozoic climate may not be straightforward. For example, the rise in seawater ${ }^{7} \mathrm{Li} /{ }^{6} \mathrm{Li}$, a tracer of chemical weathering, occurs $\sim 20 \mathrm{My}$ before the rise of seawater ${ }^{87} \mathrm{Sr} /{ }^{86} \mathrm{Sr}$, a tracer of the source of weathered material, making it difficult to attribute both to the Himalayan orogeny (Misra and Froelich, 2012; Raymo and Ruddiman, 1992). Finally, because the collision of India with 
Eurasia around $\sim 50 \mathrm{Ma}$ coincides with the shift from continental arcs in southern and eastern Eurasia to the initiation of intra-oceanic arcs in the western Pacific, disentangling the relative effects of continental arcs, continental collisions, and island arcs on seawater isotope proxies may be difficult.

\section{Summary and future directions}

Our analysis shows that magmatism, uplift and erosion are intimately linked, and hence, these connections should be considered in understanding the evolution of magmatic arcs. Importantly, if continental arcs emit large quantities of $\mathrm{CO}_{2}$ and if the generation of juvenile crust in the form of long mountain belts enhances chemical weathering, global flare-ups in continental arc magmatism should influence long-term climate evolution. If global continental arc flare-ups indeed lead to greenhouse conditions, icehouse conditions may then be a direct consequence of these flare-ups due to the protracted weathering of remnant topography after magmatism wanes. Currently, explanations for long-lived greenhouse or icehouse conditions typically invoke unique and unrelated processes, such as the emplacement of large igneous provinces for greenhouses and continental collisions for icehouses. The concepts presented here provide an internally consistent way to explain why long-term climatic baselines change.

A full test of the climatic implications of our model will ultimately require conversion of our model outputs into $\mathrm{CO}_{2}$ volcanic inputs and carbonate and organic carbon outputs. In the meantime, there are some potentially fruitful avenues for testing these hypotheses. One is to track global flare-ups in continental arc magmatism using detrital zircon geochronology, under the likely assumption that zircons predominantly derive from felsic rocks, which are more abundant in continental arcs than in island arcs and flood basalts. For example, detritical zircon geochronology has now been used to show that the cold climate of Ediacaran times coincides with a lull in global continental arc magmatism, while the greenhouse climate of the Cambrian coincides with a global flare up in continental arc magmatism (McKenzie et al., 2014). Extending these concepts throughout the Phanerozoic would be ideal. A second test would be to better quantify how erosion fluxes vary with time, using the composition and mineralogy of siliciclastics to constrain how the intensity of weathering changes during and after magmatic episodes. 
Acknowledgments

We thank Tien Chang Lee and Peter Molnar for detailed informal reviews, insight and encouragement. The paper was improved by comments from an anonymous reviewer and especially Ken Caldeira. Richard Zeebe, Francis Albarede, Adrian Lenardic, Rajdeep Dasgupta, Monica Erdman, Jade Star Lackey, Douglas Morton, Ryan McKenzie, Jeremy Caves, Hehe Jiang, Michael Farner, Mark Jellinek, Yusuke Yokoyama and the Rice Loony Noons crowd provided additional feedback. This work was supported by Frontiers of Earth System Dynamics program through the United States National Science Foundation (OCE-1338842) and represents a contribution from the CIA group at Rice (www.arc2climate.org).

643

\section{Table 1. Symbols}

Symbol

units description

$\begin{array}{lll}h & \mathrm{~km} & \text { elevation }\end{array}$

$H$

$\mathrm{km}$

excess thickness relative to continental crust at sea level

$\mathrm{km}$

total thickness of continental crust

650

$h_{b}$

$\mathrm{km}$

$h_{e c} \quad \mathrm{~km}$

651

652

653

$H_{e c}$

$\mathrm{km}$

baseline thickness of continental crust at sea level

$H_{e c}, \max \mathrm{km}$

654

$\rho_{c}$

$\mathrm{g} / \mathrm{cm}^{3}$

$\rho_{e c}$

$\mathrm{g} / \mathrm{cm}^{3}$

655

$\rho_{m}$

$\mathrm{g} / \mathrm{cm}^{3}$

$656 t$

$657 \quad M$

$\mathrm{km} / \mathrm{My}$

658

$M_{\max }$

$\mathrm{km} / \mathrm{My}$

$659 \quad E$

660

661

662

663

$\beta$

$\mathrm{km} / \mathrm{My}$

$w$

$\mathrm{km} / \mathrm{y}$

$\mathrm{km}$

664

$\tau_{E}=w / \beta$

$\mathrm{mm} / \mathrm{y}$

665

$\tau_{E}=\left(k_{e} p\right)^{-1}$

My

666

$$
\tau_{L} \equiv \tau_{E} /\left(1-\rho_{c} / \rho_{m}\right) \quad \text { Мy }
$$

$$
H_{\infty}=M \tau_{L}
$$

$\mathrm{km}$

668

$$
h_{\infty}=M \tau_{E}
$$

$\mathrm{km}$

$669 P$

$670 \quad P_{o}$

$671 \quad D$

672

673

674

675

$$
z
$$

$P$

$$
\begin{aligned}
& P_{o} \\
& D
\end{aligned}
$$

$\mathrm{m}$ $\mathrm{km} / \mathrm{My}$

$$
z_{\infty}=D \ln \left(P_{o} / E\right)
$$

$\mathrm{m}$

$$
\tau_{\text {res }}
$$

$k_{w}$ depth to garnet pyroxenite $(65 \mathrm{~km})$

thickness of eclogite layer maximum thickness of eclogite layer before foundering depth-averaged density of continental crust $\left(2.87 \mathrm{~g} / \mathrm{cm}^{3}\right)$ density of garnet pyroxenite $\left(3.5 \mathrm{~g} / \mathrm{cm}^{3}\right)$ density of mantle peridotite $\left(3.33 \mathrm{~g} / \mathrm{cm}^{3}\right)$ time $(\mathrm{My}=$ millions of years; $\mathrm{Ma}=$ millions of years ago)

magmatic flux $\left(\mathrm{km}^{3} \mathrm{~km}^{-2} \mathrm{My}^{-1}\right)$

peak magmatic flux

erosion rate

erosional constant

width of active arc

precipitation rate

erosional response time

erosional response time

landform response time

steady state excess thickness for constant $\dot{M}$

steady state elevation for constant $\dot{M}$

soil mantle thickness

soil production rate

soil production rate when $\mathrm{z}=0$

e-fold decay lengthscale of soil production function $P$

soil formation response time

steady state soil mantle thickness

soil residence time

kinetic rate constant for chemical weathering (inverse response time)

fraction of weatherable material remaining in soil

fraction of material lost by chemical weathering 


\section{FIGURES}

Figure 1. A. Global continental elevation $h$ versus crustal thickness $H$ at 1 degree resolution from the Crust 1.0 model at http://igppweb.ucsd.edu/ gabi/rem.html (Laske et al., 2013). Data have been broken down into major physiographic provinces. Lines represent plausible $h-H$ relationships for different average crustal densities, following Eq. 3 in the Section 2.1 and assuming the seafloor $(4 \mathrm{~km})$ as a common base level. Reference mantle density is assumed to be $3.33 \mathrm{~g} / \mathrm{cm}^{3}$ (Lee, 2003). B. Same as in A except data points are not categorized. This plot shows the time evolution of $h$ and $H$ with magmatic thickening with a $M(t)$ relationship shown in the inset. Most importantly, this model assumes a reference mantle density of $3.33 \mathrm{~g} / \mathrm{cm}^{3}$ and an average crustal density of 2.87 , which is obtained from A. Model results with these density relationships can reproduce observed $h-H$ behavior.

Figure 2. A. Concept of an isostatically compensated crustal column. $\mathrm{H}_{\text {total }}=$ total crustal thickness, $\mathrm{h}=$ elevation above sea level, $h_{b}=$ thickness of background continental crust at sea level, $r=$ root thickness, $w$ $=$ width of mountain range, $\rho_{\mathrm{c}}=$ density of crust, $\rho_{\mathrm{m}}=$ density of mantle, $\mathrm{M}=$ magmatic production rate, and $\mathrm{E}=$ erosion rate. $\mathrm{B}$. Same as in A except dense garnet pyroxenite layer forms at the base of the crust, $\mathrm{h}_{\mathrm{px}}=$ depth at which garnet pyroxenite forms and $\mathrm{H}_{\mathrm{px}}=$ thickness of pyroxenite layer.

Figure 3. Idealized model outputs. Models involve an instantaneous onset of magmatism, which is sustained indefinitely at a constant value. Indefinite sustainment of magmatism is unrealistic, but done here to explore general behaviors. In A-C, no pyroxenite layer forms. In D-F, pyroxenite layer forms if crustal thickness $\mathrm{H}$ exceeds $65 \mathrm{~km}$, but is removed instantaneously if the pyroxenite layer thickness itself exceeds $35 \mathrm{~km}$. Isostasy is assumed. A and D. Magmatic flux M and erosion rate for different erosional response times $\tau_{\mathrm{E}}$ as a function of time. B and E. Evolution of crustal thickness $\mathrm{H}$. C and F. Evolution of elevation $h$. In D-F, generation of pyroxenite layer followed by foundering results in cyclic thickening and thinning of crust and rise and fall of elevations.

Figure 4. A. Idealized geologic map of California (Jennings, 1958) showing Cretaceous continental arc plutons and surrounding Paleozoic and Early Mesozoic sedimentary rocks, many of which were metamorphosed during contact metamorphism. B. Idealized cartoon of a continental arc, showing where and how magmas might interact with sedimentary carbonates stored in the continental upper plate. C. Global chain of continental arcs during the Cretaceous modified from (Lee et al., 2013).

Figure 5. A. Histogram of U-Pb zircon ages for the Sierra Nevada batholith (Cao et al., 2015; Paterson et al., 2014; Paterson et al., 2011). B. Total volumetric magma production for the Sierra Nevada batholith. Black dashed curve includes only the crust above the Moho taken to be $35 \mathrm{~km}$ (Paterson et al., 2014; Paterson et al., 2011). Red curve includes mafic cumulates (down to $70 \mathrm{~km}$ ) and is thus more representative of the total magmatic input. C. Paleo-depth estimates in the batholith versus time based on Al-in-hornblende barometry and U-Th/He and apatite fission track thermochronology (Ague and Brimhall, 1988; Cecil et al., 2006; House et al., 1997; Paterson et al., 2014; Wakabayashi and Sawyer, 2001). D. Paleo-elevation of surface markers (Paterson et al., 2014). Dashed lines represent speculative elevation-time paths between data points.

Figure 6. Simulation of Sierran magmatic flare-up between 120 and $80 \mathrm{Ma}$, where peak magmatic flux occurs at $100 \mathrm{Ma}$. Model results for the case in which pyroxenite does not form. Left hand column (AD) corresponds to peak magmatic flux $M_{\max }$ of $1.8 \mathrm{~km} / \mathrm{My}$ and right hand column $(\mathrm{E}-\mathrm{H})$ is for $M_{\max }=3.2$ $\mathrm{km} / \mathrm{My}$. A and E represent magmatic flux and erosion rates versus time for different erosional response 
times. B and $\mathrm{F}$ represent evolution of crustal thickness. C and $\mathrm{G}$ represent evolution of elevation. D and $\mathrm{H}$ represent the cumulative magma added and material eroded.

726

727

728

729

730

731

732

733

734

735

736

737

738

739

740

741

742

743

744

745

746

747

748

749

750

751

752

753

754

755

756

757

758

759

760

761

762

763

764

765

766
Figure 7. Simulation of Sierran magmatic flare-up between 120 and $80 \mathrm{Ma}$, where peak magmatic flux occurs at $100 \mathrm{Ma}$. Model results for the case in which pyroxenite formation occurs at depths greater than $h_{p x}=65 \mathrm{~km}$ and peak magmatic flux of $3.2 \mathrm{~km} / \mathrm{My}$. Results are shown for different erosional response times. A-D symbols as in Figure 6. Orange horizontal line in B represents depth beyond which pyroxenite forms.

Figure 8. Simulation of Sierran magmatic flare-up. Modeled erosion rates are compared to observed erosion rates (gray areas) determined by differentiating paleo-depth versus time curves in Figure 5c. A. No pyroxenite and peak magmatism $M_{\max }=1.8 \mathrm{~km} / \mathrm{My}$. B. No pyroxenite, $\mathrm{M}_{\max }=3.2 \mathrm{~km} / \mathrm{My}$. C. Pyroxenite forms at depths beyond $65 \mathrm{~km}, \mathrm{M}_{\max }=3.2 \mathrm{~km} / \mathrm{My}$.

Figure 9. A. Cartoon illustrating the soil formation model. Thickness of soil mantle on a mountain is controlled by bedrock to soil conversion $P$ and erosion $E$. Rate of bedrock to soil conversion is assumed to decay exponentially with depth over a characteristic decay length $D$. B. Time for a soil mantle to reach steady-state thickness as a function of erosion rate. C. For a steady-state soil mantle profile, residence time of material in the soil mantle as a function of erosion rate.

Figure 10. Chemical weathering effects modeled for Sierran magmatic flare-up. A. Erosion rate and magmatic flux versus time for $\mathrm{M}_{\max }=3.2 \mathrm{~km} / \mathrm{My}, \tau_{\mathrm{E}}=6 \mathrm{My}$ and $\mathrm{h}_{\mathrm{px}}=65 \mathrm{~km}$. Figure 10a is essentially the same as in Figure 7a. B and C. Chemical weathering effects for $D=30 \mathrm{~m}$ and $1 / k_{w}=0.01 \mathrm{My}$ for a range of $P_{o}$. B represents chemical weathering flux and $\mathrm{C}$ represents intensity of weathering $\left(1-f_{w}\right)$. D and $\mathrm{E}$ are similar to $\mathrm{B}$ and $\mathrm{C}$ except that $P_{o}$ is held constant and $k_{w}$ is varied. $D$ remains at $30 \mathrm{~m}$. Horizontal orange and blue bars correspond to possible greenhouse and icehouse intervals.

Ague, J.J., Brimhall, G.H., 1988. Magmatic arc asymmetry and distribution of anomalous plutonic belts in the batholiths of California: effects of assimilation, crustal thickness and depth of crystallization. Geological Society of America Bulletin 100, 912-927.

Bateman, P.C., Eaton, J.P., 1967. The Sierra Nevada Batholith. Science 158, 1407-1417.

Berner, R.A., 1991. A model for atmospheric $\mathrm{CO}_{2}$ over Phanerozoic time. Am. J. Sci. 291, 339-376. Berner, R.A., Caldeira, K., 1997. The need for mass balance and feedback in the geochemical carbon cycle. Geology 25, 955-956.

Berner, R.A., Lasaga, A.C., Garrels, R.M., 1983. The carbonate-silicate geochemical cycle and its effect on atmospheric carbon dioxide over the past 100 million years. Am. J. Sci. 284, 641-683.

Bird, P., 1991. Lateral extrusion of lower crust from under high topography, in the isostatic limit. J. Geophys. Res. 96, 10275-10286.

Burton, M.R., Sawyer, G.M., Granieri, D., 2013. Deep carbon emissions from volcanoes. Reviews in Mineralogy and Geochemistry 75, 323-354.

Caldeira, K., Kasting, J.F., 1992. The life span of the biosphere revisited. Nature 360, 721-723.

Cao, W., Paterson, S.R., Memeti, V., Mundil, R., Anderson, J.L., Schmidt, K., 2015. Tracking

paleodeformation fields in the Mesozoic central Sierra Nevada arc: implications for intra-arc cyclic deformation and arc tempos. Lithosphere.

Cecil, M.R., Ducea, M., Reiners, P.W., Chase, C.G., 2006. Cenozoic exhumation of the northern Sierra Nevada, California, from (U-Th)/He thermochronology. Geol. Soc. Am. Bull. 118, 1481-1488. 
Chadwick, J.P., Troll, V.R., Ginibre, C., Morgan, D., Gertisser, R., Waight, T.E., Davidson, J.P., 2007. Carbonate assimilation at Merapi volcano, Java, Indonesia: insights from crystal isotope stratigraphy. J. Petrol. 48, 1793-1812.

Chin, E.J., Lee, C.-T.A., Blichert-Toft, J., 2015. Growth of upper plate lithosphere controls tempo of arc magmatism: constraints from Al-diffusion kinetics and coupled Lu-Hf and Sm-Nd chronology. Geochemical Perspectives Letters 1, 20-32. Culling, W.E.H., 1960. Analytical theory of erosion. Journal of Geology 68, 336-344. Dasgupta, R., 2013. Ingassing, storage, and outgassing of terrestrial carbon through geologic time. Rev. Mineralogy and Geochemistry 75, 183-229.

Dasgupta, R., Hirschmann, M.M., 2010. The deep carbon cycle and melting in Earth's interior. Earth Planet. Sci. Lett. 298, 1-13.

DeBari, S.M., Sleep, N.H., 1991. High-Mg, low-Al bulk composition of the Talkeetna island arc, Alaska: implications for primary magmas and the nature of arc crust. Geological Society of America Bulletin 103, 37-47.

Deegan, F.M., Troll, V.R., Freda, C., Misiti, V., Chadwick, J.P., McLeod, C.L., Davidson, J.P., 2010. Magmacarbonate interaction processes and associated $\mathrm{CO}_{2}$ release at Merapi volcano, Indonesia: insights from experimental petrology. J. Petrol. 51, 1027-1051.

Dixon, J.L., Hartshorn, A.S., Heimsath, A.M., DiBiase, R.A., Whipple, K.X., 2012. Chemical weathering response to tectonic forcing: a soils perspective from the San Gabriel Mountains, California. Earth Planet. Sci. Lett. 323-324, 40-49. Ducea, M.N., Barton, M.D., 2007. Igniting flare-up events in Cordilleran arcs. Geology 35, 1047-1050. Ducea, M.N., Saleeby, J.B., 1996. Buoyancy sources for a large, unrooted mountain range, the Sierra Nevada, California: evidence from xenolith thermobarometry. Journ. Geophys. Res. 101, 8229-8244. Ducea, M.N., Saleeby, J.B., Bergantz, G., 2015. The architecture, chemistry, and evolution of continental magmatic arcs. Annual Reviews of Earth and Planetary Sciences 43, 10.11-10.33. Edmond, J.M., 1992. Himalayan tectonics, weathering processes and the strontium isotope record in marine limestones. Science 258, 1594-1597.

England, P., Molnar, P., 1990. Surface uplift, uplift of rocks, and exhumation of rocks. Geology 18, 11731177.

Ferrier, K.L., Kirchner, J.W., 2008. Effects of physical erosion on chemical denudation rates: a numerical modeling study of soil-mantle hillslopes. Earth Planet. Sci. Lett. 272, 591-599.

France-Lanord, C., Derry, L.A., 1997. Organic carbon burial forcing of the carbon cycle from Himalayan erosion. Nature 390, 65-67.

Gaillardet, J., Dupre, B., Louvat, P., Allegre, C.J., 1999. Global silicate weathering and $\mathrm{CO}_{2}$ consumption rates deduced from the chemistry of large rivers. Chem. Geol. 159, 3-30.

Greene, A.R., DeBari, S.M., Kelemen, P.B., Blusztajn, J., Clift, P.D., 2006. A detailed geochemical study of island arc crust: the Talkeetna arc section south-central Alaska. Journal of Petrology 47, 1051-1093. Heimsath, A.M., Dietrich, W.E., Nishiizumi, K., Finkel, R.C., 1997. The soil production function and landscape equilibrium. Nature 388, 358-361.

Hilley, G.E., Chamberlain, C.P., Moon, S., Porder, S., Willett, S.D., 2010. Competition between erosion and reaction kinetics in controlling silicate-weathering rates. Earth and Planetary Science Letters 293, 191-199.

Hilton, D.R., Fischer, T., Marty, B., 2002. Noble gases and volatile recycling at subduction zones, Reviews in Mineralogy and Geochemistry, pp. 319-370.

Hong, S.K., Lee, Y.I., 2012. Evaluation of atmospheric carbon dioxide concentrations during the Cretaceous. Earth Planet. Sci. Lett. 327-328, 23-28.

House, M.A., Wernicke, B.P., Farley, K.A., 1998. Dating topography of the Sierra Nevada, California, using apatite (U-Th)/He ages. Nature 396, 66-69. 
House, M.A., Wernicke, B.P., Farley, K.A., Dumitru, T., 1997. Cenozoic thermal evolution of the central Sierra Nevada, California, from (U-Th)/He thermochronometry. Earth Planet. Sci. Lett. 151, 167-179. Huber, N.K., 1981. Amount and timing of late Cenozoic uplift and tilt of the central Sierra Nevada, California - evidence from the upper San Joaquin River Basin. U. S. Geol. Survey Professional Paper 1197, 28.

Ishizuka, O., Tani, K., Reagan, M.K., 2014. Izu-Bonin-Mariana forearc crust as a modern ophiolite analogue. Elements 10, 115-120.

Jadamec, M.A., Turcotte, D.L., Howell, P., 2007. Analytica models for orogenic collapse. Tectonophyiscs 435, 1-12.

Jagoutz, O., Schmidt, M.W., 2012. The formation and bulk composition of modern juvenile continental crust: the Kohistan arc. Chemical Geology 298-299, 79-96.

Jennings, C.W., 1958. Geologic Map of California. California Division of Mines and Geology.

Karlstrom, L., Lee, C.-T.A., Manga, M., 2014. The role of magmatically driven lithospheric thickening on arc front migration. Geochem. Geophys. Geosys. 15.

Kerrick, D.M., 2001. Present and past nonanthropogenic $\mathrm{CO}_{2}$ degassing from the solid Earth. Reviews of Geophysics 39, 565-585.

Kerrick, D.M., Caldeira, K., 1994. Metamorphic $\mathrm{CO}_{2}$ degassing and early Cenozoic paleoclimate. Geol. Soc. Am. Today 4, 57-65.

Kerrick, D.M., Connolly, J.A.D., 2001. Metamorphic devolatilization of subducted marine sediments and transport of volatiles into the Earth's mantle. Nature 411, 293-296.

Kidder, D.L., Worsley, T.R., 2010. Phanerozoic large igneous provinces (LIPs), HEATT (Haline Euxinic Acidic Thermal Transgression) episodes, and mass extinctions. Palaeogeography, Palaeoclimatology, Palaeoecology 295, 162-191.

Larson, R.L., 1991. Latest pulse of Earth: evidence for a mid-Cretaceous superplume. Geology 19, 547550.

Laske, G., Masters, G., Ma, Z., Pasyanos, M., 2013. Update on CRUST1.0 - A 1-degree global model of Earth's crust. Geophys. Res. Abstracts, EGU2013-2658.

Lee, C.-T.A., 2003. Compositional variation of density and seismic velocities in natural peridotites at STP conditions: implications for seismic imaging of compositional heterogeneities in the upper mantle. Journ. Geophys. Res. 108.

Lee, C.-T.A., 2014. Physics and chemistry of deep continental crust recycling. Treatise of Geochemistry 4, 423-456.

Lee, C.-T.A., Cheng, X., Horodyskyj, U., 2006. The development and refinement of continental arcs by primary basaltic magmatism, garnet pyroxenite accumulation, basaltic recharge and delamination: insights from the Sierra Nevada, California. Contributions to Mineral Petrology 151, 222-242. Lee, C.-T.A., Lackey, J.S., 2015. Global continental arc flare-ups and their relation to long-term greenhouse conditions. Elements 11, 125-130.

Lee, C.-T.A., Morton, D.M., Kistler, R.W., Baird, A.K., 2007. Petrology and tectonics of Phanerozoic continent formation: from island arcs to accretion and continental arc magmatism. Earth and Planetary Science Letters 263, 370-387.

Lee, C.-T.A., Shen, B., Slotnick, B.S., Liao, K., Dickens, G.R., Yokoyama, Y., Lenardic, A., Dasgupta, R., Jellinek, M., Lackey, J.S., Schneider, T., Tice, M., 2013. Continental arc-island arc fluctuations, growth of crustal carbonates and long-term climate change. Geosphere 9, 21-36.

Lindgren, W., 1911. The Tertiary gravels of the Sierra Nevada of California. Maher, K., Chamberlain, C.P., 2014. Hydrologic regulation of chemical weathering and the geologic carbon cycle. Science 343, 1502-1504.

Marty, B., Tolstikhin, I.N., 1998. $\mathrm{CO}_{2}$ fluxes from mid-ocean ridges, arcs and plumes. Chem. Geol. 145, 233-248. 
McKenzie, N.R., Hughes, N.C., Gill, B.C., Myrow, P.M., 2014. Plate tectonic influences on Neoproterozoicearly Paleozoic climate and animal evolution. Geology.

Millot, R., Gaillardet, J., Dupre, B., Allegre, C.J., 2002. The global control of silicate weathering rates and the coupling with physical erosion: new insights from rivers of the Canadian shield. Earth Planet. Sci. Lett. 196, 83-98.

Misra, S., Froelich, P.N., 2012. Lithium isotope history of Cenozoic seawater: changes in silicate weathering and reverse weathering. Science 335, 818-823.

Molnar, P., England, P., 1990. Late Cenozoic uplift of mountain ranges and global climate change: chicken or egg? Nature 346, 29-34.

Molnar, P., Lyon-Caen, H., 1988. Some simple physical aspects of the support, structure, and evolution of mountain belts. Geol. Soc. Am. Spec. Paper 218, 179-207.

Montgomery, D.R., Balco, G., Willett, S.D., 2001. Climate, tectonics, and the morphology of the Andes. Geology 29, 579-582.

Paterson, S.R., Ducea, M.N., 2015. Arc magmatic tempos: gathering the evidence. Elements 11, 91-98. Paterson, S.R., Memeti, V., 2014. Day 5: Mesozoic volcanic rocks of the central Sierra Nevada Arc, in: Memeti, V., Paterson, S.R., Putirka, K.D. (Eds.), Formation of the Sierra Nevada batholith: magmatic and tectonic processes and their tempos, pp. 75-85.

Paterson, S.R., Memeti, V., Anderson, L., Cao, W., Lackey, J.S., Putirka, K.D., Miller, R.B., Miller, J.S., Mundil, R., 2014. Day 6: overview of arc processes and tempos, in: Memeti, V., Paterson, S.R., Putirka, K.D. (Eds.), Formation of the Sierra Nevada batholith: magmatic and tectonic processes and their tempos, pp. 87-116.

Paterson, S.R., Memeti, V., Economos, R., Miller, R.B., 2011. Magma addition and flux calculations of incrementally constructed magma chambers in continental margin arcs: combined field, geochronologic, and thermal modeling studies. Geosphere 7, 1439-1468.

Poage, M.A., Chamberlain, C.P., 2002. Stable isotopic evidence for a pre-Middle Miocene rain shadow in the western Basin and Range: implications for the paleotopography of the Sierra Nevada. Tectonics 21. Raymo, M.E., Ruddiman, W.F., 1992. Tectonic forcing of late Cenozoic climate. Nature 359, 117-122. Ridgwell, A., Zeebe, R.E., 2005. The role of the global carbonate cycle in the regulation and evolution of the Earth system. Earth Planet. Sci. Lett. 234, 299-315.

Simoes, M., Braun, J., Bonnet, S., 2010. Continental-scale erosion and transport laws: a new approach to quantitatively investigate macroscale landscapes and associated sediment fluxes over the geological past. Geochem. Geophys. Geosys. 11, Q09001.

Sleep, N.H., 1971. Thermal effects of the formation of Atlantic continental margins by continental break up. Geophysical Journal of the Royal Astronomical Society 24, 325-350.

Toutain, J.-P., Sortino, F., Baubron, J.-C., Richon, P., Surono, Sumarti, S., Nonell, A., 2009. Structure and $\mathrm{CO}_{2}$ budget of Merapi volcano during inter-eruptive periods. Bull. Volcanol. 71, 815-826.

Wakabayashi, J., Sawyer, T.L., 2001. Stream incision, tectonics, uplift, and evolution of topography of the Sierra Nevada, California. J. Geology 109, 539-562.

Walker, J.C.G., Hays, P.B., Kasting, J.F., 1981. A negative feedback mechanism for the long-term stabilization of Earth's surface temperature. J. Geophys. Res. 86, 9776-9782.

West, J., 2012. Thickness of the chemical weathering zone and implications for erosional and climatic drivers of weathering and for carbon-cycle feedbacks. Geology 40, 811-814.

West, J., Galy, A., Bickle, M., 2005. Tectonic and climatic controls on silicate weathering. Earth and Planetary Science Letters 235, 211-228.

Willet, S.D., Brandon, M.T., 2002. On steady states in mountain belts. Geology 30, 175-178. $\mathrm{Wu}, \mathrm{W} ., \mathrm{Xu}, \mathrm{S}$., Yang, J., Yin, $\mathrm{H} ., 2$ 2008. Silicate weathering and $\mathrm{CO}_{2}$ consumption deduced from the seven Chinese rivers originating in the Qinghai Tibet Plateau. Chem. Geol. 249, 307-320. 
910 Zachos, J.C., Dickens, G.R., Zeebe, R.E., 2008. An early Cenozoic perspective on greenhouse warming and 911 carbon-cycle dynamics. Nature 451, 279-283.

912 Zachos, J.C., Kump, L.R., 2005. Carbon cycle feedbacks and the initiation of Antarctic glaciation in the 913 earliest Oligocene. Global and planetary change 47, 51-66.

914 Zeebe, R.E., Caldeira, K., 2008. Close mass balance of long-term carbon fluxes from ice-core $\mathrm{CO}_{2}$ and 915 ocean chemistry records. Nature Geoscience 1, 312-315.

916

917 
Figure 1

A

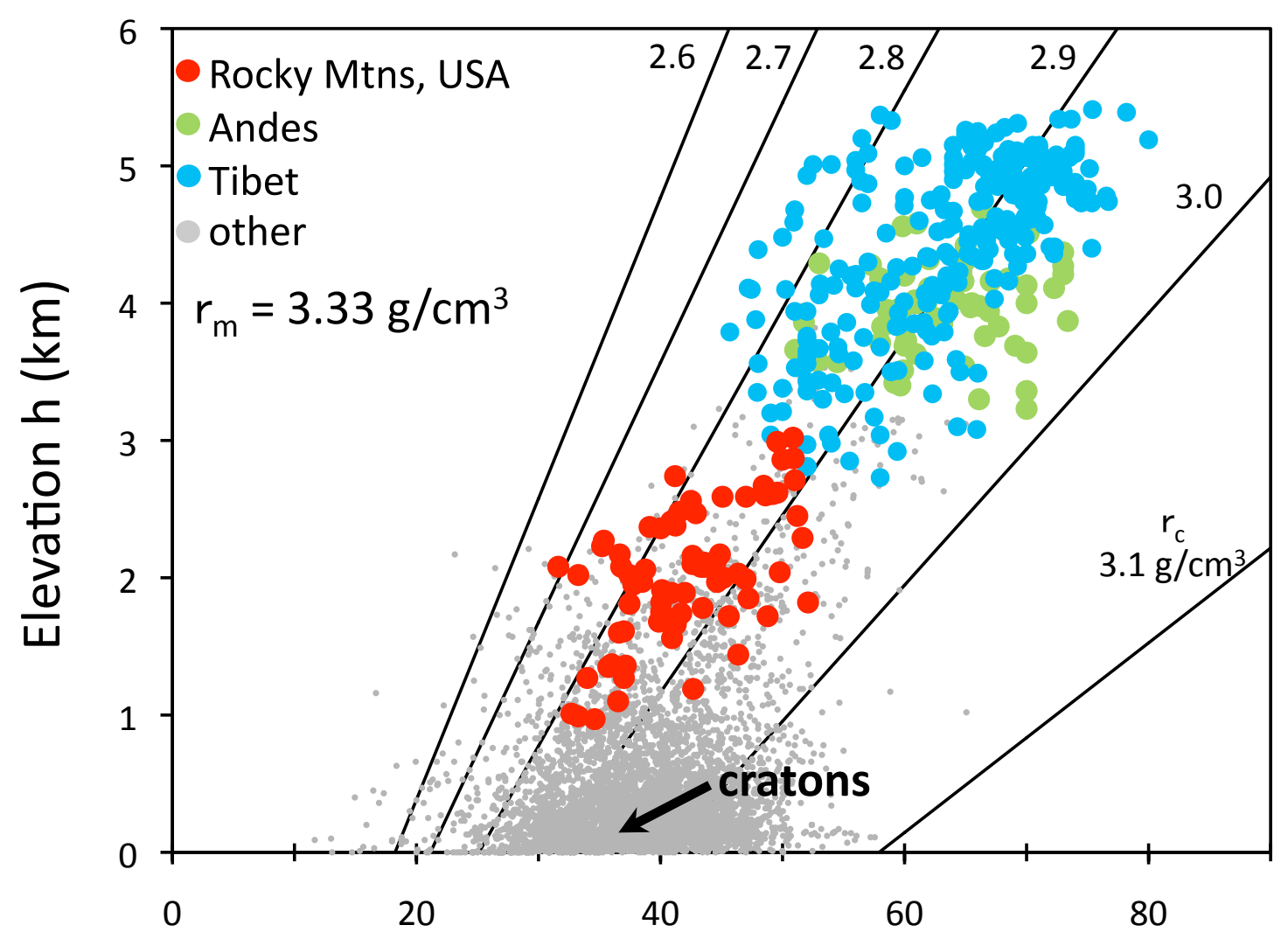

B

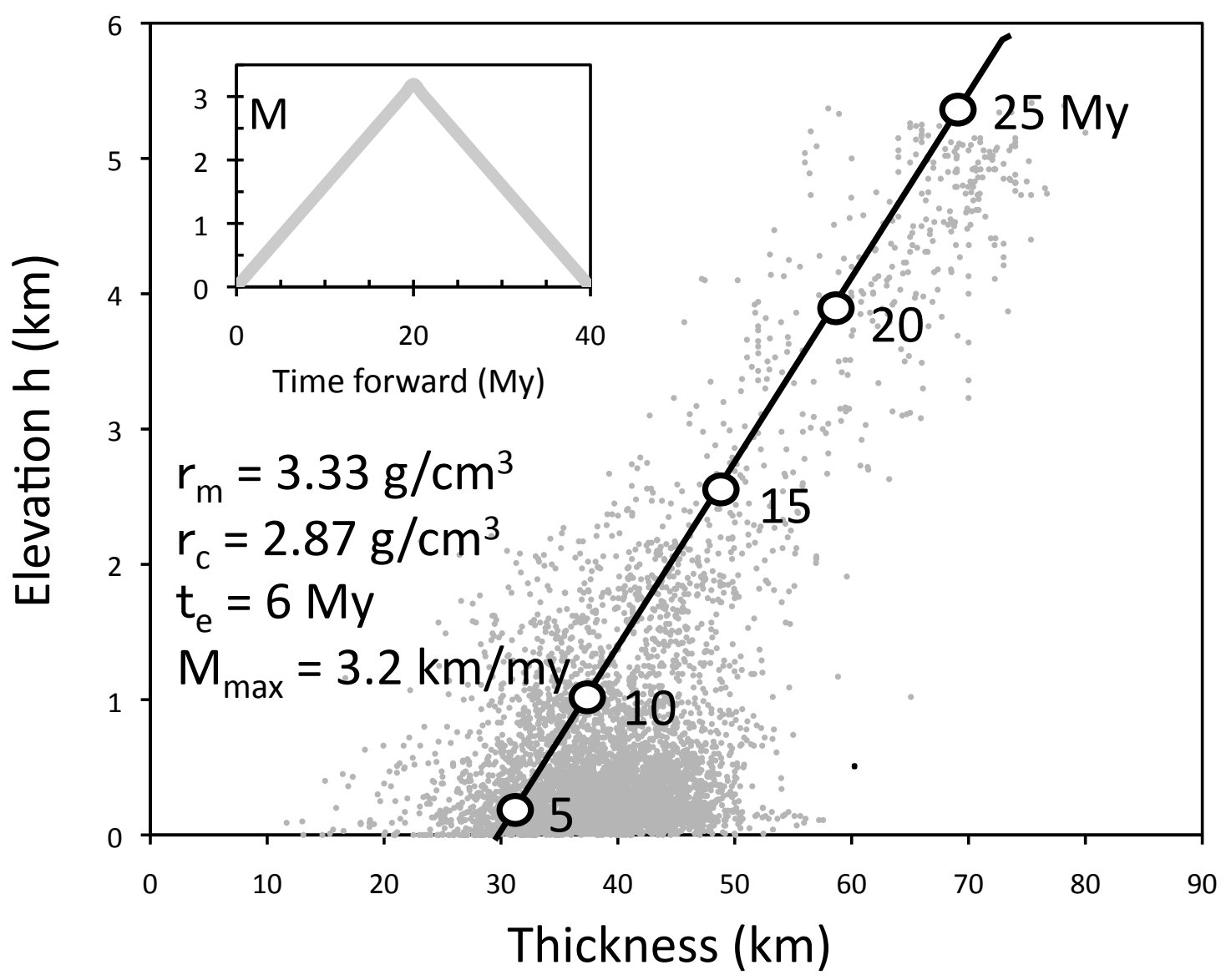


Figure 2

A

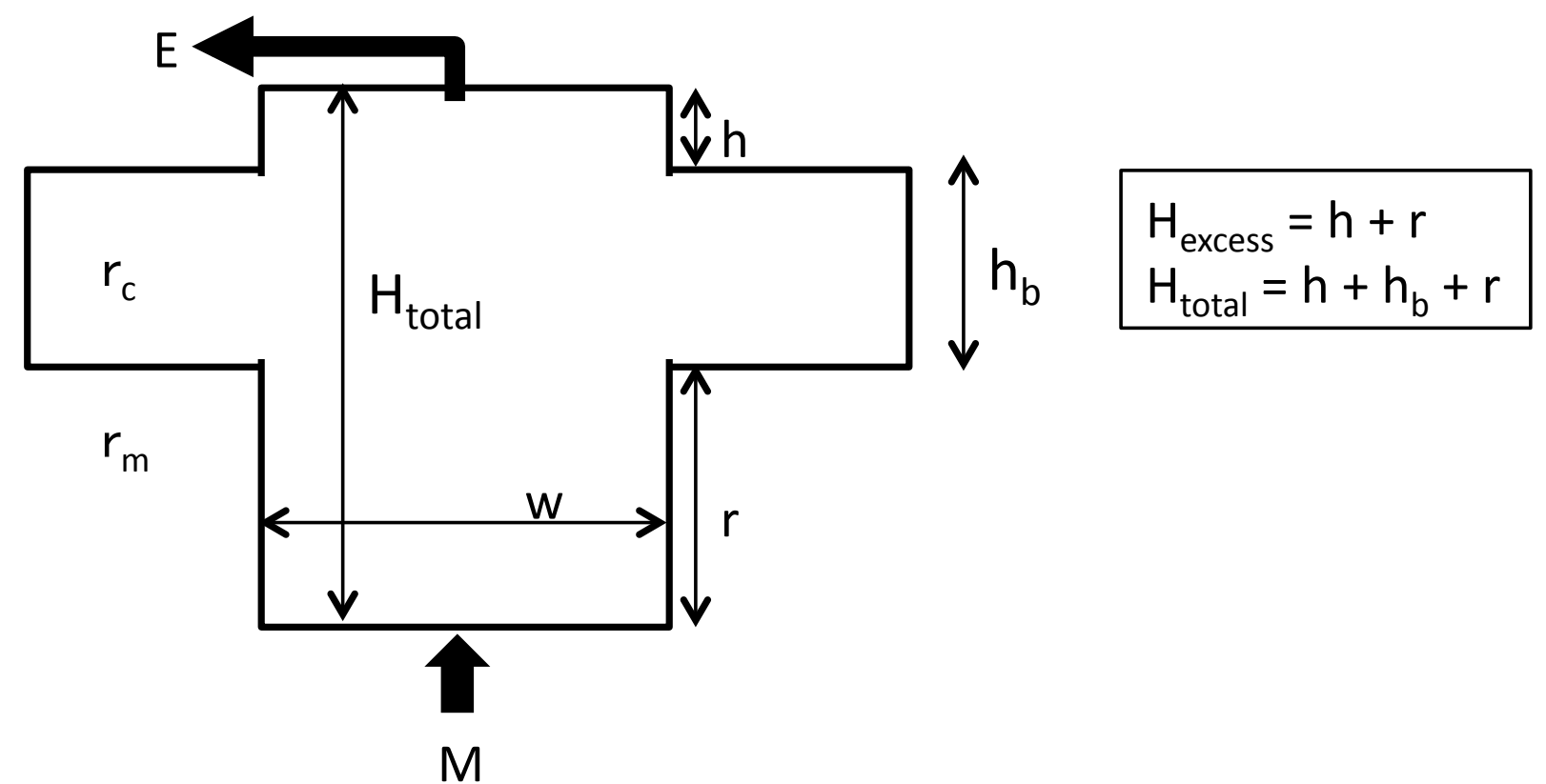

B

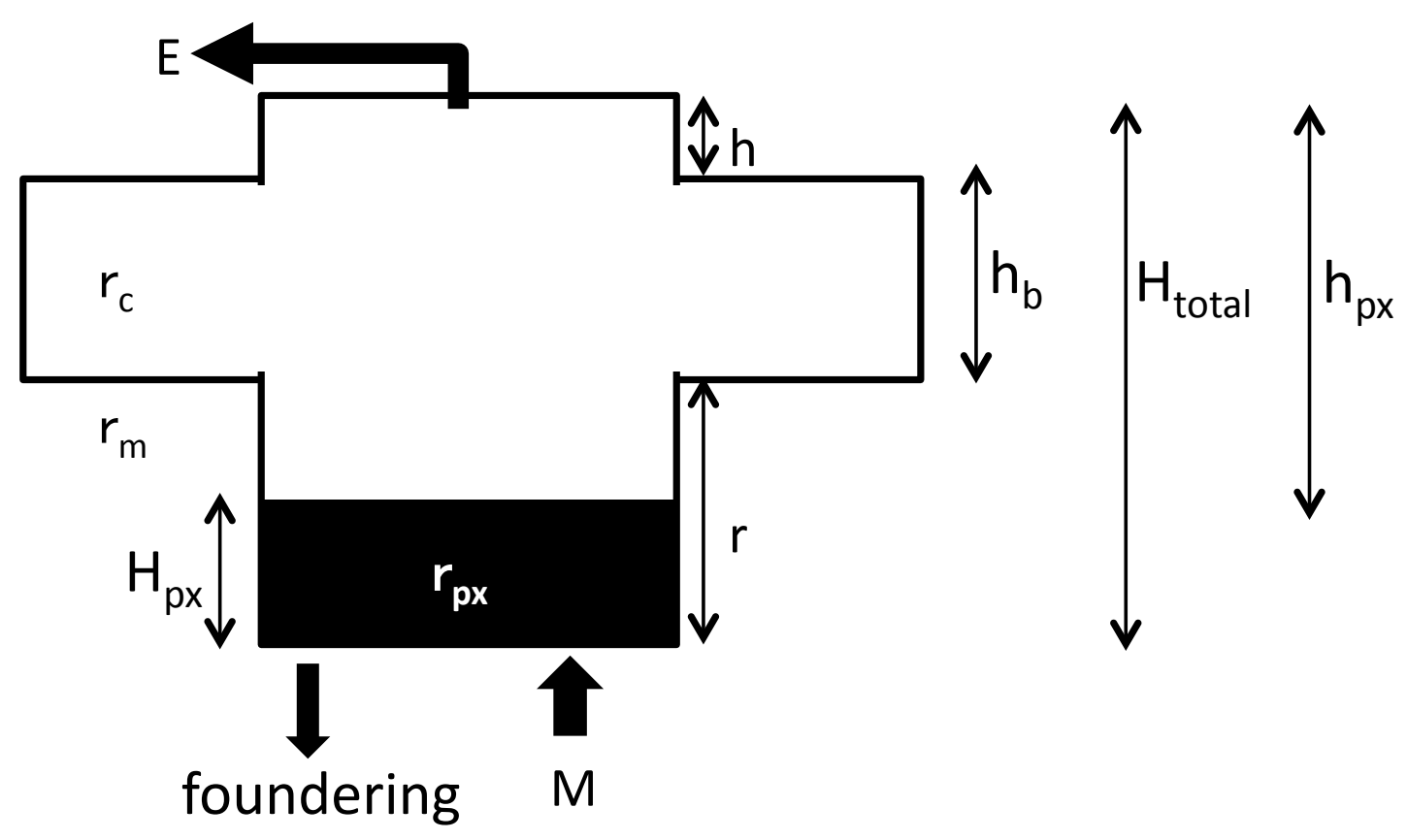


Figure 3

No pyroxenite
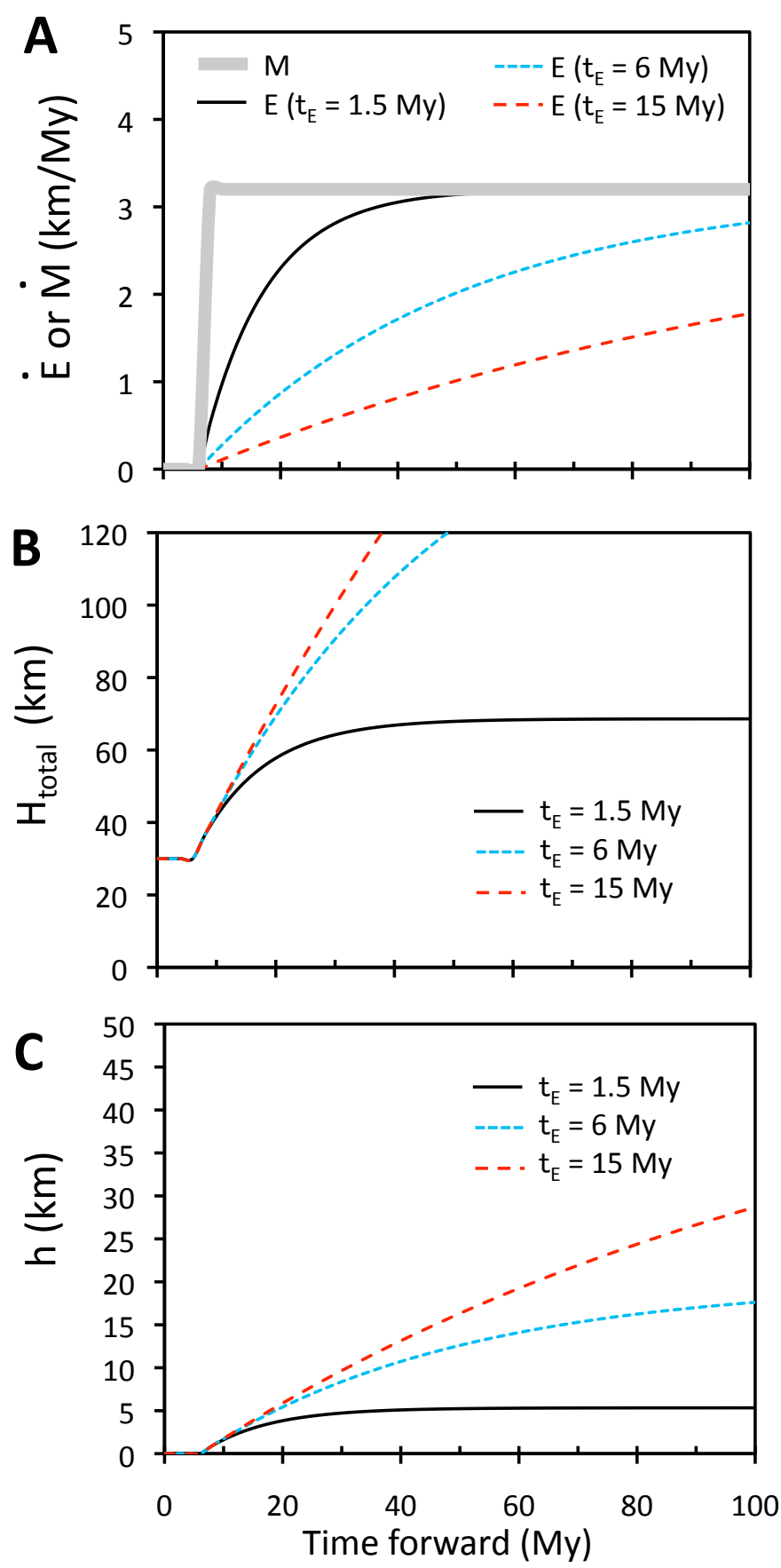

\section{Pyroxenite + Foundering}

$\mathrm{h}_{\mathrm{ec}}=65 \mathrm{~km} ; \mathrm{H}_{\mathrm{ec} \max }=35 \mathrm{~km} ; \mathrm{r}_{\mathrm{ec}}=3.5 \mathrm{~g} / \mathrm{cm}^{3}$
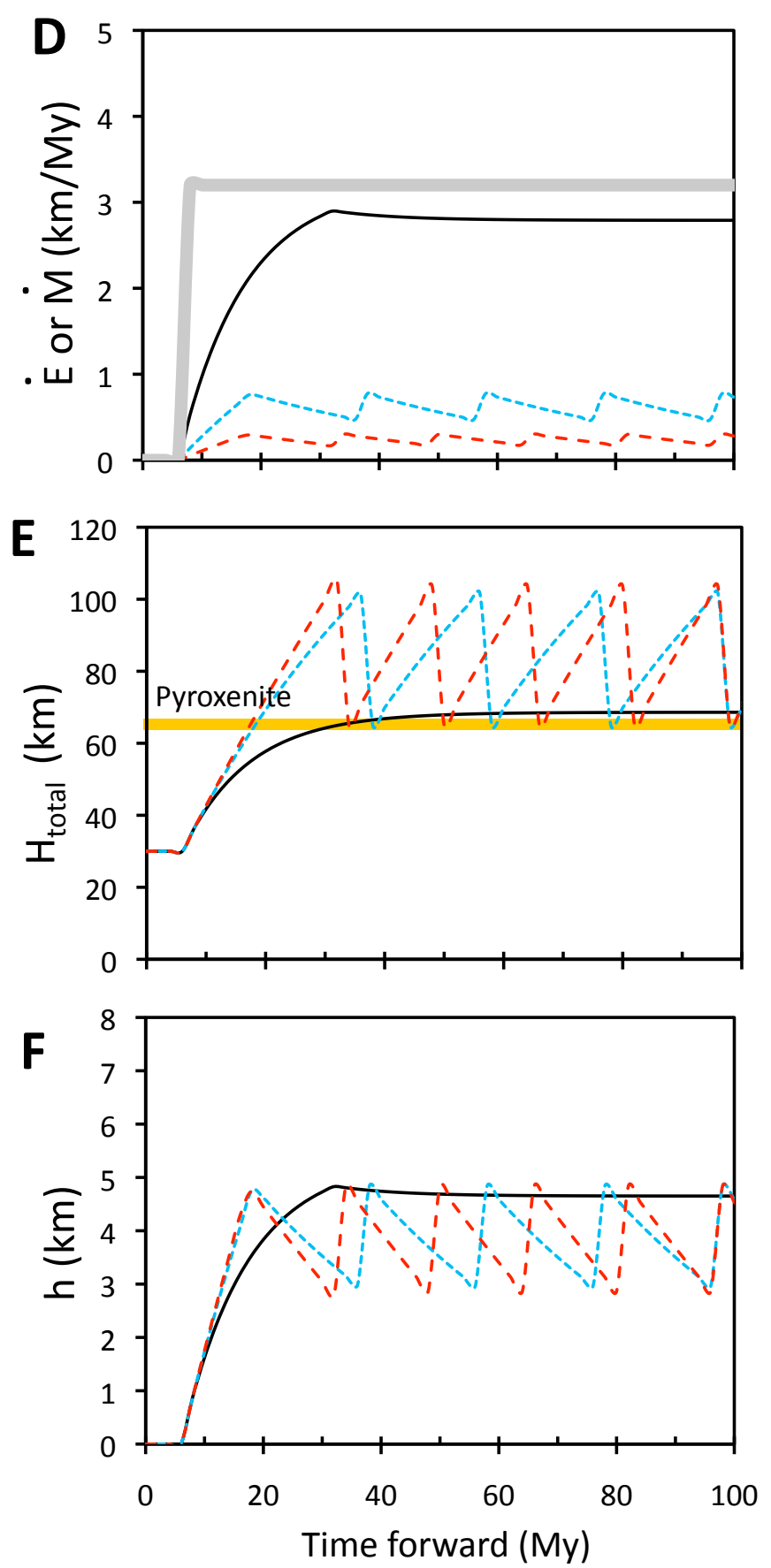
Figure 4

A

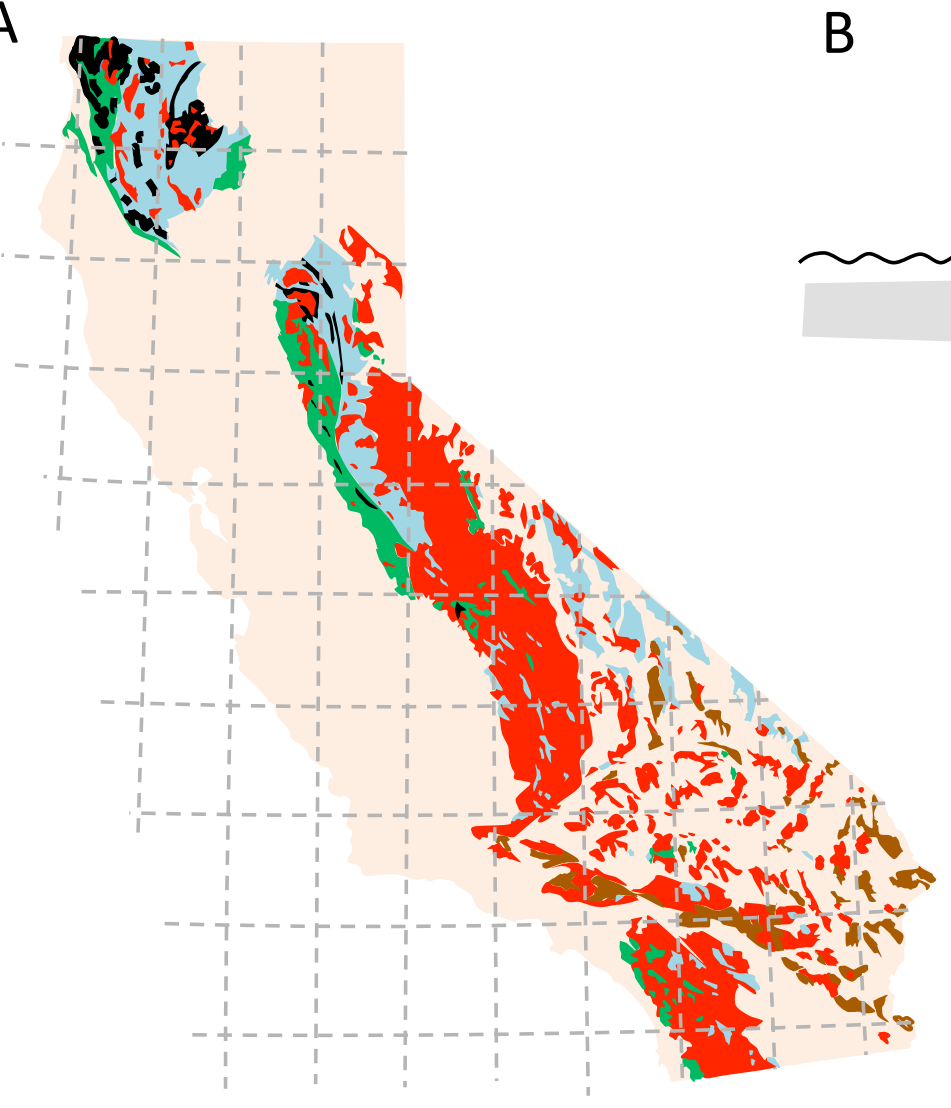

Cretaceous Igneous

Jurassic sediments/volcanics

Paleozoic sediments/volcanics

Precambrian
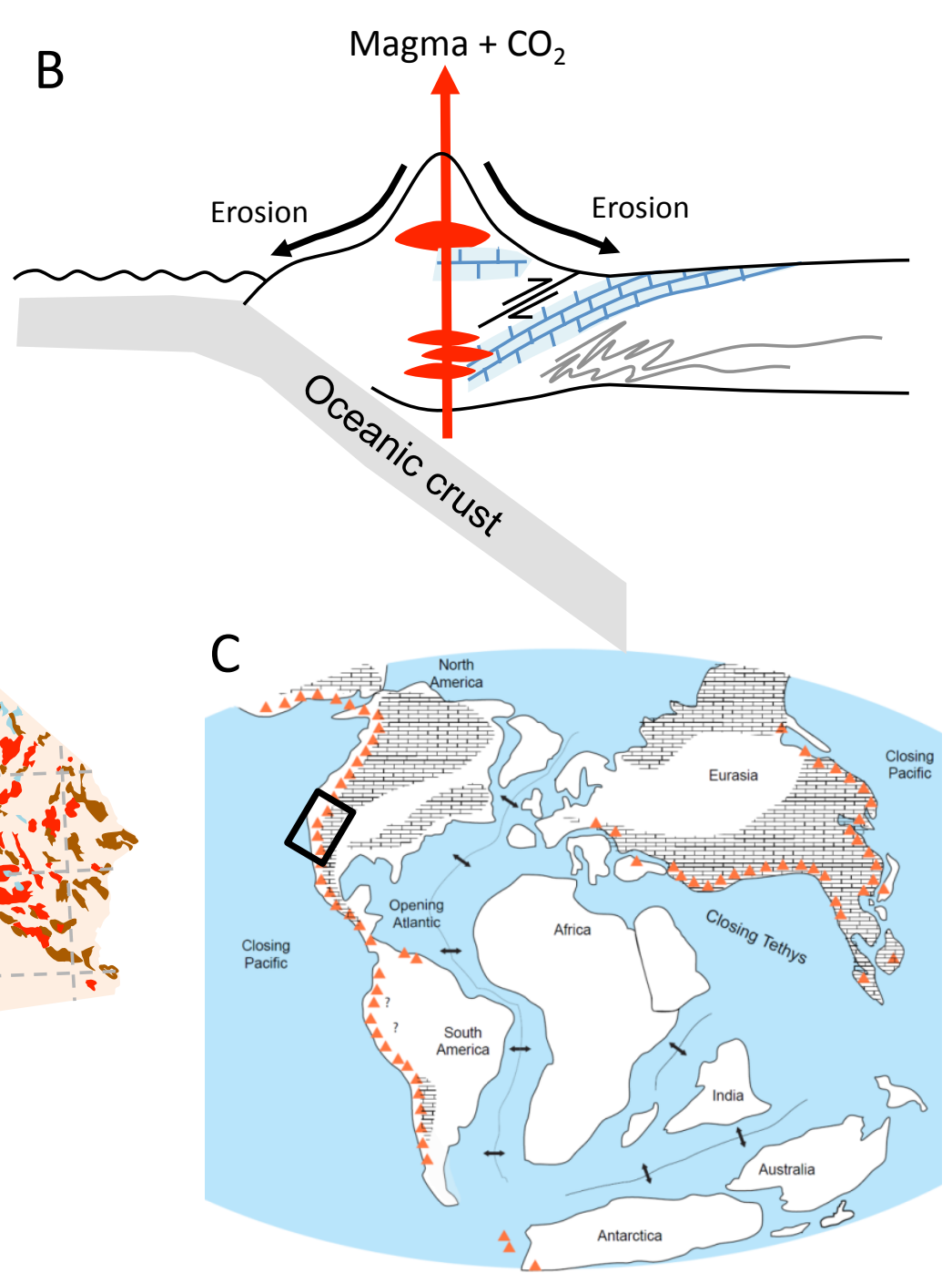
Figure 5
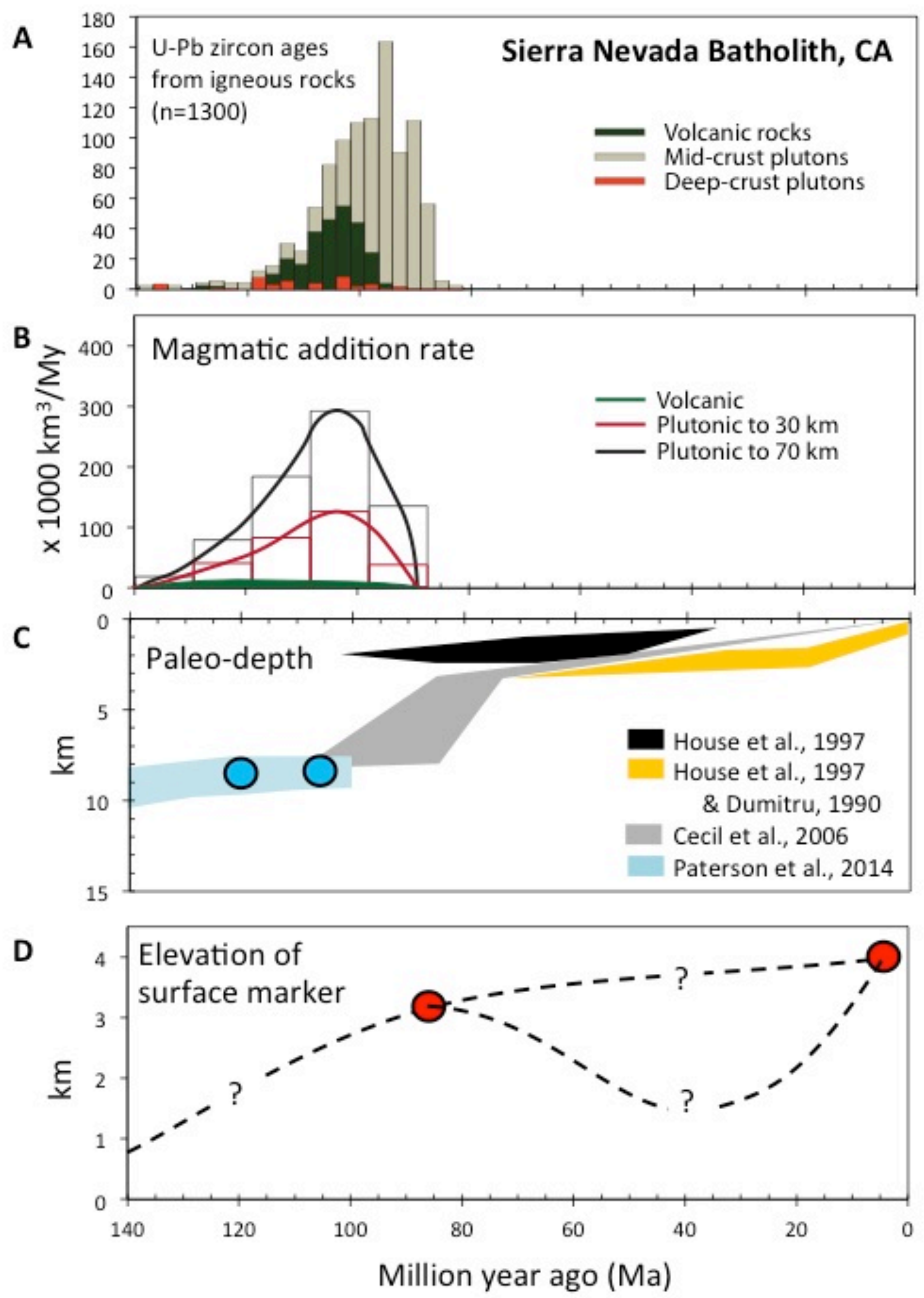
Figure 6
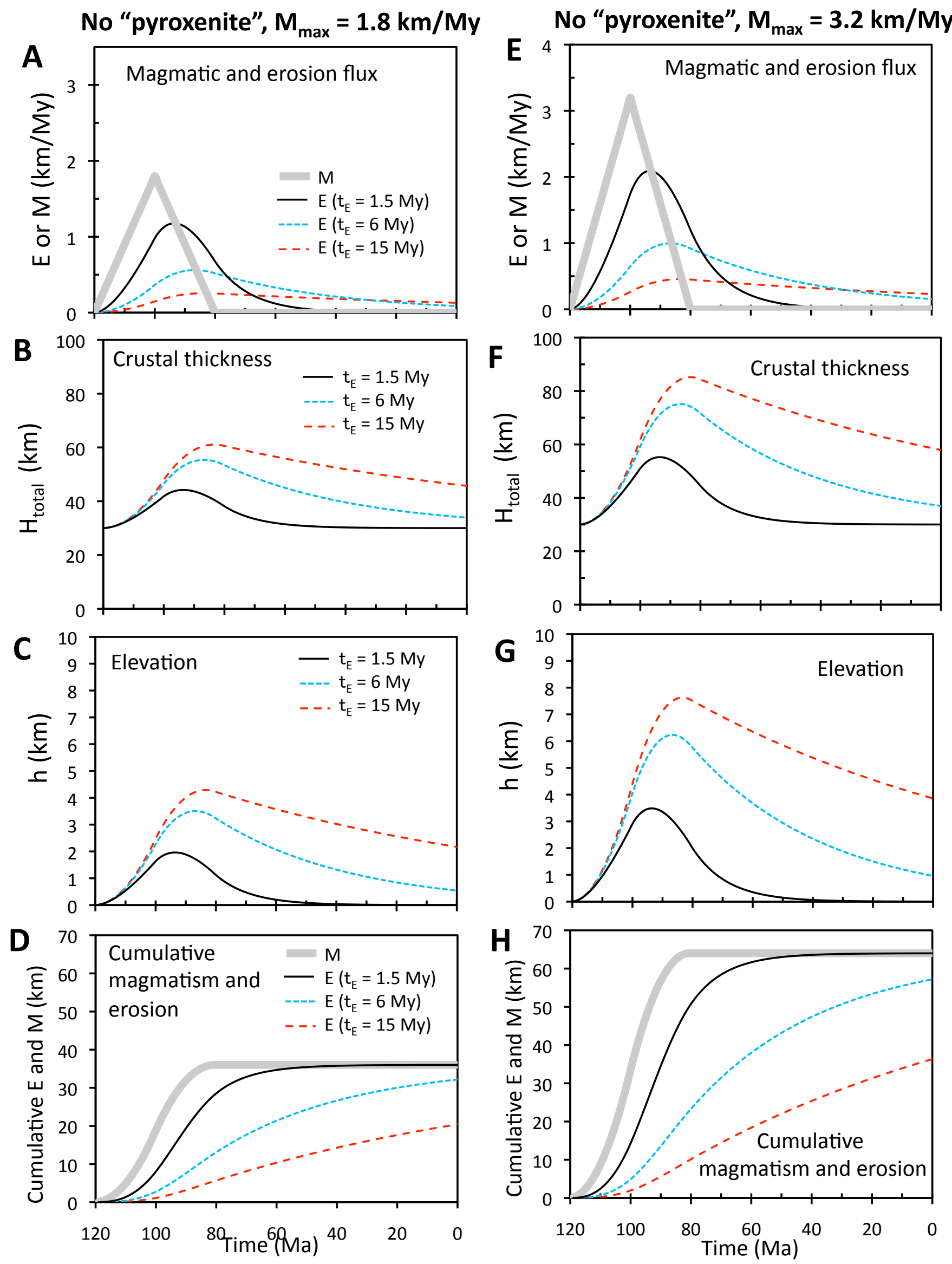
Figure 7

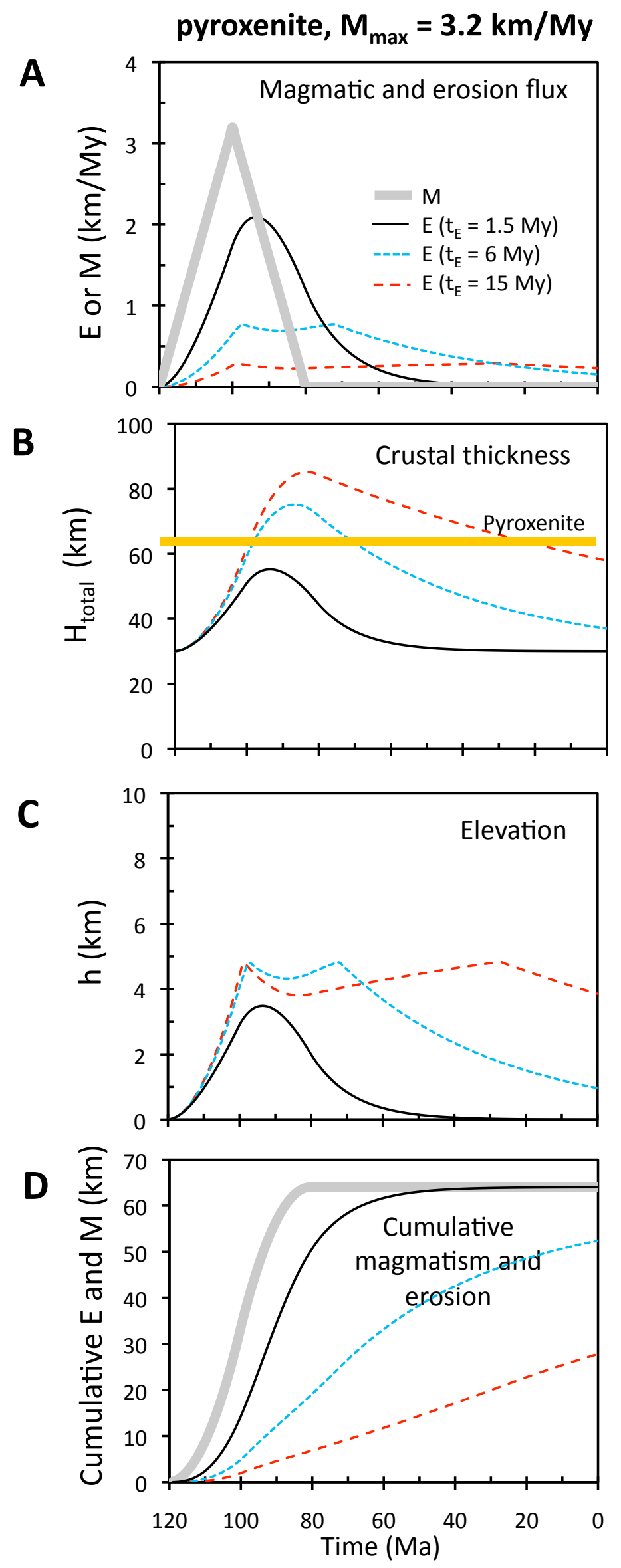


Figure 8
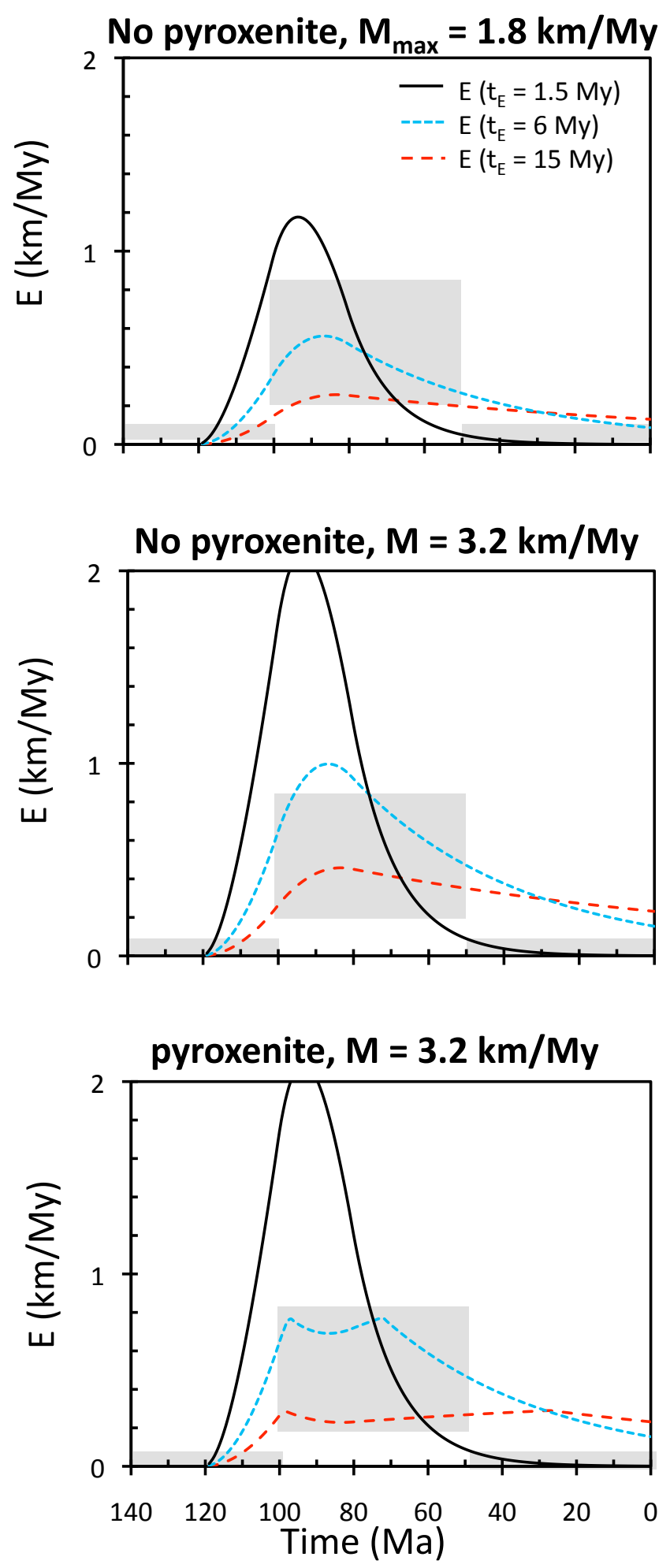
Figure 9

A
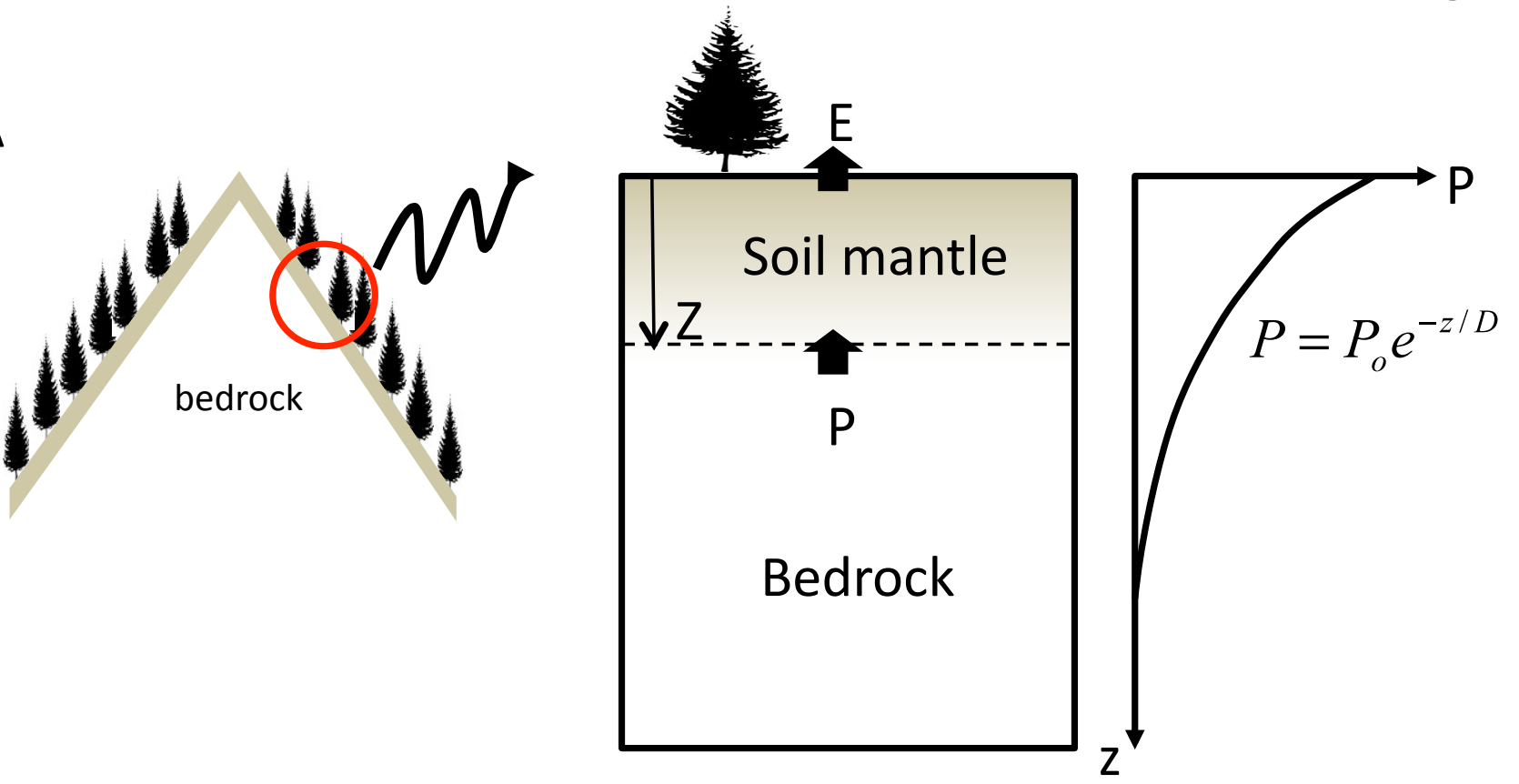

B

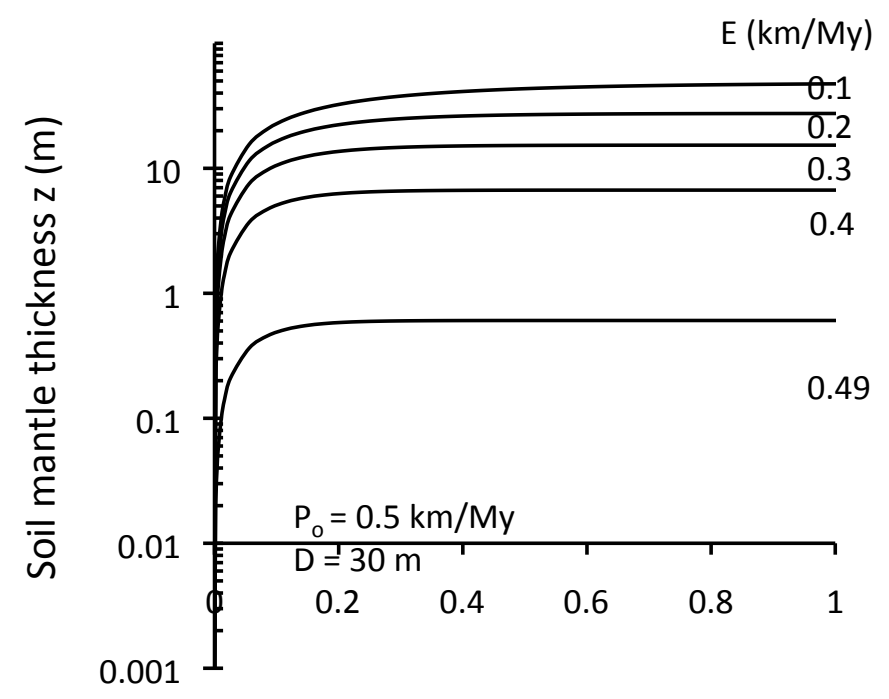

C

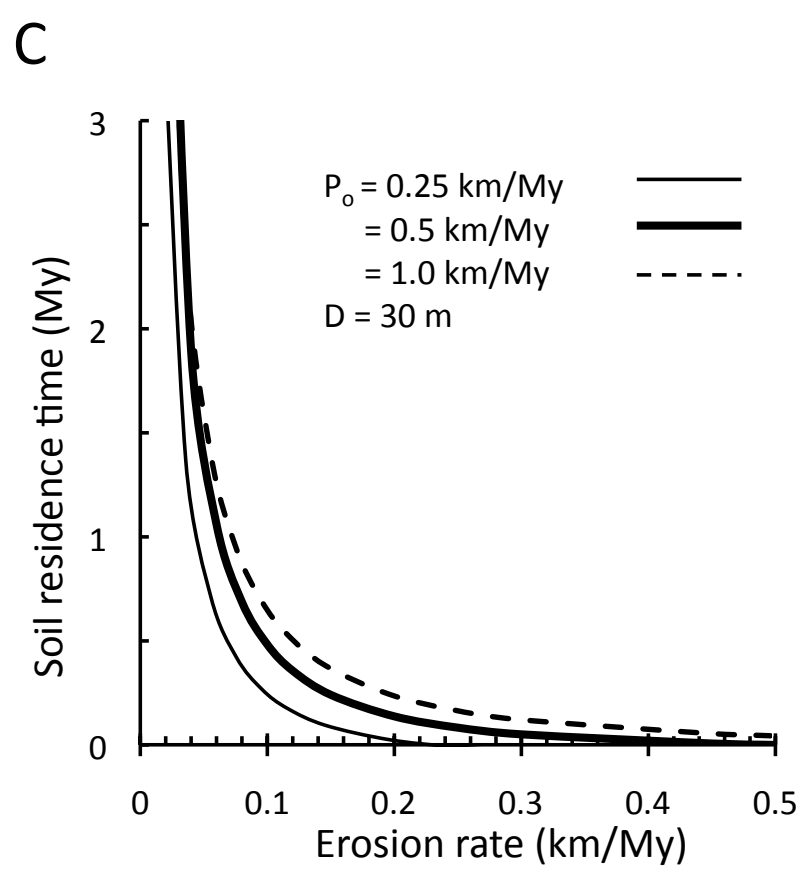

time (My) 


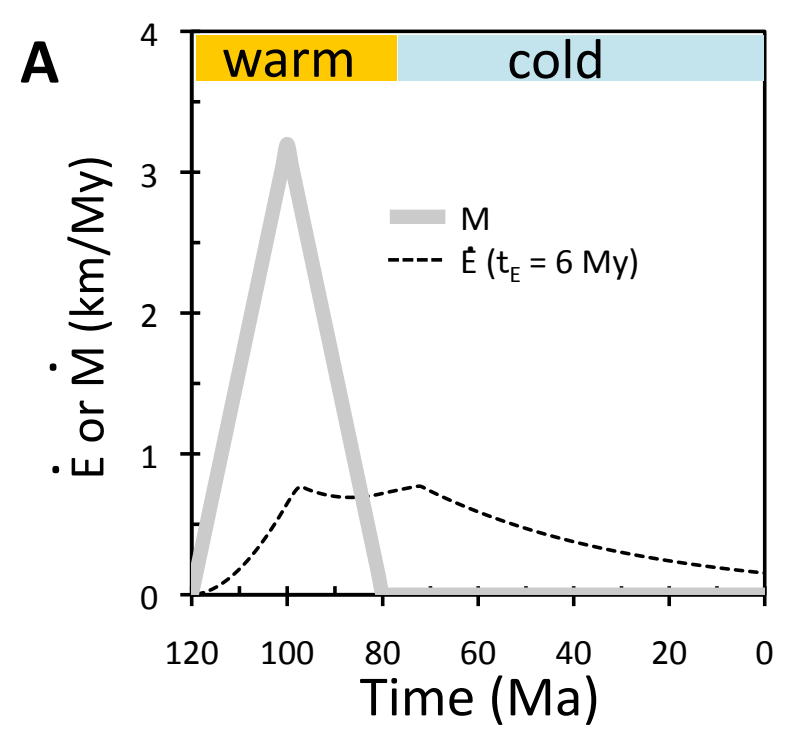

Figure 10

\section{$P_{o}$ variable; $D=30 \mathrm{~m} ; 1 / k_{w}=0.01 \mathrm{My}$}
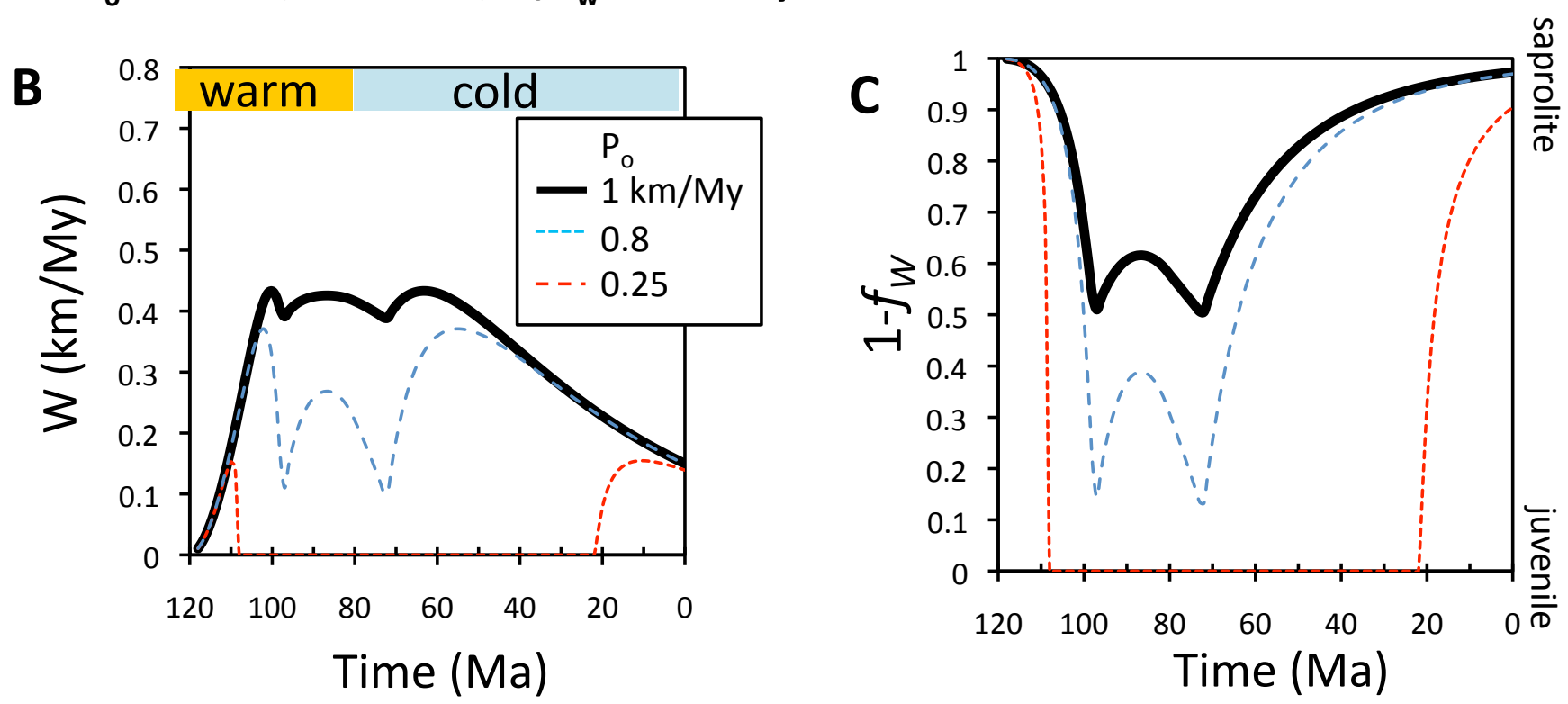

$k_{w}$ variable; $D=30 \mathrm{~m} ; P_{o}=1 \mathrm{~km} / \mathrm{My}$
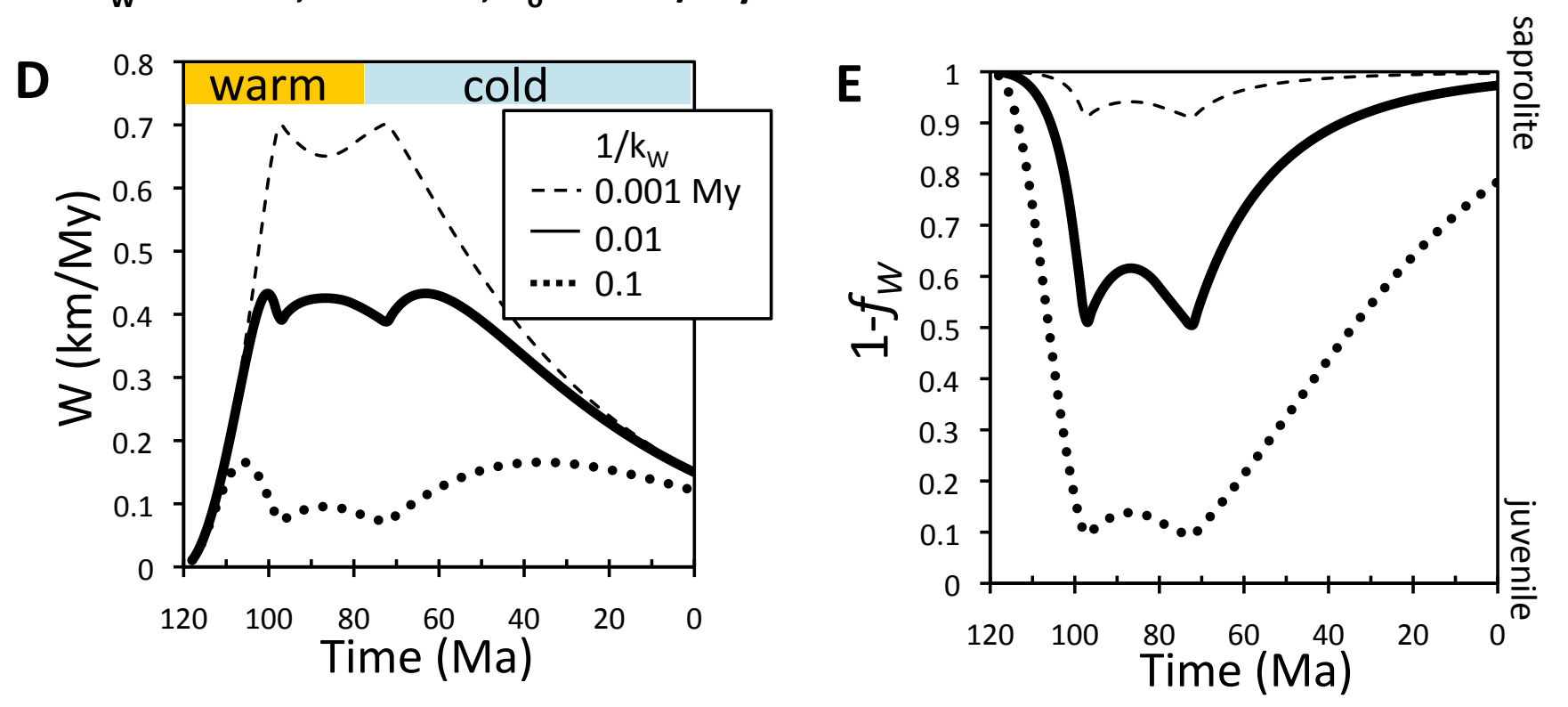